\title{
31. MAGNETOSTRATIGRAPHY OF UPPER JURASSIC AND LOWEST CRETACEOUS SEDIMENTS, DEEP SEA DRILLING PROJECT SITE 534, WESTERN NORTH ATLANTIC1
}

\author{
James G. Ogg, ${ }^{2}$ Department of Geology and Geophysics, University of Wyoming, Laramie, Wyoming
}

\begin{abstract}
Kimmeridgian-Tithonian red marly limestones and Berriasian white limestones were recovered at Site 534 of DSDP Leg 76 in the western North Atlantic. These yielded a well-defined magnetostratigraphy with the characteristic magnetization carried by hematite in red sediments and magnetite in white sediments. The polarity sequence is correlated to the magnetostratigraphy of Kimmeridgian-Tithonian-Berriasian pelagic carbonates of northern Italy and southern Spain, allowing precise biostratigraphic age correlations. The Berriasian/Tithonian boundary occurs within the upper half of Core 90, the late Tithonian/early Tithonian boundary at the base of Core 96, and the Tithonian/Kimmeridgian boundary at the top of Core 102 . Correlations are also made to M-16 through M-22 of the marine magnetic anomaly $\mathrm{M}$-sequence. Poor recovery and irregular magnetic properties of the underlying Kimmeridgian-Oxfordian-Callovian marls and claystones prevented determination of a polarity sequence, but the entire interval has mixed polarity. Valanginian gray marly limestones have very weak magnetizations, and preliminary results are inadequate to determine the polarity pattern.
\end{abstract}

\section{INTRODUCTION}

Site 534 of Leg 76 of the Deep Sea Drilling Project was drilled $220 \mathrm{~km}$ north-northeast of the Bahama Islands $\left(28^{\circ} \mathrm{N}, 285^{\circ} \mathrm{E}\right)$. This part of the Blake-Bahama Basin has a series of low-amplitude marine magnetic anomalies that are older than M-25 of the M-sequence of Larson and Hilde (1975), and the Site was drilled on "M-28" of Bryan et al. (1980). At the Site, drilling penetrated $30 \mathrm{~m}$ into the pillow basalts underlying $1635 \mathrm{~m}$ of sediments. The lowest $300 \mathrm{~m}$ were in Jurassic marls and claystones, and the basal marls have middle to late Callovian assemblages of nannofossils (Roth et al., this volume), dinoflagellates (Habib, this volume), and radiolarians (Baumgartner, this volume). Recovery of the thick overlying Lower Cretaceous limestones and marly limestone units was excellent (approximately $90 \%$ for the $200 \mathrm{~m}$ of Berriasian and Valanginian limestones).

The goal of this paleomagnetic project was to identify the polarity sequence in the Jurassic, Berriasian, and Valanginian sediments and to correlate the pattern to the magnetostratigraphy of other sediment sections and to the M-sequence of marine magnetic anomalies. Currently, the M-sequence has been reliably correlated to well-dated sediment sections only in partial segments: M-0 to M-4 with upper Barremian-Aptian pelagic carbonates in northern Italy (Channell et al., 1977, 1979), and M-17 to M-24 with Kimmeridgian-Tithonian-lower Berriasian pelagic limestones in northern Italy and southern Spain (Ogg, 1980, 1981; Ogg et al., unpublished data). It was hoped that Site 534 would allow extension of the dating of the $\mathrm{M}$-sequence and solve the puzzle of the lack of well-defined marine magnetic anomalies of high amplitude in ocean crust older than M-25.

\footnotetext{
${ }^{1}$ Sheridan, R. E., Gradstein, F. M., et al., Init. Repts. DSDP, 76: Washington (U.S. Govt, Printing Office).

2 Present address: Scripps Institution of Oceanography, A-012, University of California at San Diego, La Jolla, California.
}

\section{STRATIGRAPHY}

The Jurassic sediments of Site 534 were subdivided by the shipboard sedimentologists into two major units with seven subunits on the basis of color, composition, and the occurrence of calcareous turbidite episodes (see Site 534 report). Detailed discussions of the sedimentology, chemistry, and paleoenvironments are given in the Site 534 report and Ogg et al. (this volume).

Above the pillow basalts with rare intercalated reddish limestone are $10 \mathrm{~m}$ of dusky red silty marl (Core 127 and the lower half of Core 126). Greenish black radiolarian-rich claystone with turbidites of marly limestone abundant above Core 125 comprise the next $58 \mathrm{~m}$ (upper half of Core 126 through Core 120). The ages of these two lithologies span the middle to late Callovian and perhaps a portion of the Oxfordian (for a summary of the biostratigraphy, see Gradstein, this volume). Recovery was poor above Core 125 .

Dark variegated claystones form the next unit between Cores 119 and 111 . The lower third of this $72-\mathrm{m}$ interval is dominated by gray limestone turbidites. The age is Oxfordian, with tentative Kimmeridgian near the top. Recovery was only about $10 \%$ in this unit.

Limestone turbidites dominate the next $67 \mathrm{~m}$ (Core 110 through the lower part of Core 103); these are intercalated with greenish gray or reddish brown marls. The age is mainly Kimmeridgian, with disagreement between the various biostratigraphic zonations. Recovery averaged less than $50 \%$ and was less than $10 \%$ in the lowest three cores.

Grayish red marls and marly limestones form the upper unit $(87 \mathrm{~m}$, upper part of Core 103 through the lower part of Core 92) and are predominately Tithonian. Recovery was excellent, except for a gap at Cores 97 to 98 .

The Lower Cretaceous Blake-Bahama Formation was subdivided into four subunits (described in detail by 
Robertson and Bliefnick, this volume), of which only the lower two were sampled in detail. The basal $90 \mathrm{~m}$ (upper part of Core 92 through Core 82) are white limestones with greenish gray clay seams. The age is Berriasian with uppermost Tithonian at the base, and recovery was excellent except for Core 82 . The overlying $51 \mathrm{~m}$ (Cores 81 through 76) are interbedded gray laminated marly limestones, light bluish gray bioturbated limestones, and dark claystones. Their age is early Valanginian, and recovery was excellent. The next $102 \mathrm{~m}$ (Cores 75 through 64) of gray chalk and laminated marl with dark claystones were sampled only as a pilot study. The age is early and late Valanginian and early Hauterivian, with excellent recovery.

Hiatuses in sedimentation have been suggested to explain the apparently sharp contacts and changes in fossil assemblages or preservation between the four major Jurassic facies and between the lowest two Cretaceous units (see discussions in Ogg et al., this volume, and Sheridan et al., this volume). The contact between the grayish red marly limestone unit (Tithonian) and white limestones (Berriasian) is transitional. The suggested hiatuses are not documented by biostratigraphic gaps, possibly as a result of the poor resolution of the biostratigraphy.

\section{METHOD}

An average of two paleomagnetic samples were taken from each $1.5-\mathrm{m}$ section of recovered sediment from Cores 76 through 127 (12 samples per core). Normally, these consisted of minicores $(2.4 \mathrm{~cm}$ diameter and length) drilled perpendicular to the axis of the core, but soft or friable claystones were collected with oriented plastic cubes. Only two samples per core were collected from Cores 75 to 66 .

The Digico spinner magnetometer aboard the Glomar Challenger proved to be unreliable for measuring weak (less than $10^{-6} \mathrm{emu} / \mathrm{cm}^{3}$ ) samples. The magnetization intensity for a sample would vary by an order of magnitude over repeated trials. Therefore, all measurements were made on two-axis ScT cryogenic magnetometers at either the University of Wyoming laboratory or the California Institute of Technology laboratory (operated by Sierra Geophysics, Inc.). Both facilities are in magnetically shielded rooms and have on-line computer data analysis. Each sample was measured in eight orientations that were then averaged. Progressive thermal demagnetization was done in noninductively wound furnaces with separate cooling chambers. Several dozen samples underwent progressive alternating field demagnetization with either a 3-axis Schonsted tumbler or single-axis Schonsted AF demagnetizer.

The background noise level of the cryogenic magnetometers is such that a spurious signal of random direction and intensity of up to $2 \times 10^{-8}$ total emu may be added to the sample measurement. Samples had a volume of $10 \mathrm{~cm}^{3}$, therefore, a measurement with an intensity of magnetization of $2 \times 10^{-7} \mathrm{emu} / \mathrm{cm}^{3}$ has an error of less than $1^{\circ}$ in direction, a measurement with $2 \times 10^{-8} \mathrm{emu} / \mathrm{cm}^{3}$ intensity has a $10^{\circ}$ precision, and so on. The DSDP cores have no horizontal orientation, therefore, one has only magnetic inclination to indicate polarity (although if one assumes a simple two-component magnetization of a removable normal overprint on a primary direction, then the shift in relative declination during progressive demagnetization can serve as a guide to true declination and hence polarity). The predicted Jurassic paleolatitudes (Steiner, this volume) imply that magnetic inclinations should be in the $15^{\circ}$ to $40^{\circ}$ range. Measurements with an intensity of $1 \times 10^{-8} \mathrm{emu} / \mathrm{cm}^{3}$ or less were generally rejected as having insufficient precision.

Several dozen samples were selected for pilot studies on the magnetic characteristics of the various lithologies and underwent stepwise thermal demagnetization in $40^{\circ}$ to $50^{\circ} \mathrm{C}$ increments or alternating field demagnetization at closely spaced increments. Based on these pilots, a batch demagnetization scheme (of NRM plus a minimum of 3 demaynetization steps) was determined for each lithology.

\section{MAGNETIC PROPERTIES OF THE LITHOLOGIES}

Dusky red silty marl (middle to late Callovian). The NRM intensities averaged about $1 \times 10^{-4} \mathrm{emu} / \mathrm{cm}^{3}$, the highest for any of the lithologies, for the ten samples analyzed from this $10-\mathrm{m}$ interval. The NRM inclinations ranged from $-1^{\circ}$ to $74^{\circ}$, with a cluster at 25 to $45^{\circ}$. Progressive AF demagnetization through 500 Oe on a typical sample (one-half of Sample 534A-127-3, $58 \mathrm{~cm}$ ) had no effect on the direction of magnetization and reduced the intensity by only $30 \%$; thermal demagnetization on the other half of the same sample resulted in a $50 \%$ reduction in intensity and $35^{\circ}$ change in inclination at the $200^{\circ} \mathrm{C}$ step. This sharp decrease in intensity upon thermal demagnetization at low temperatures $\left(150^{\circ}-\right.$ $200^{\circ} \mathrm{C}$ ) was characteristic. A typical thermal demagnetization behavior is shown in Figure 1 (this sample dis-

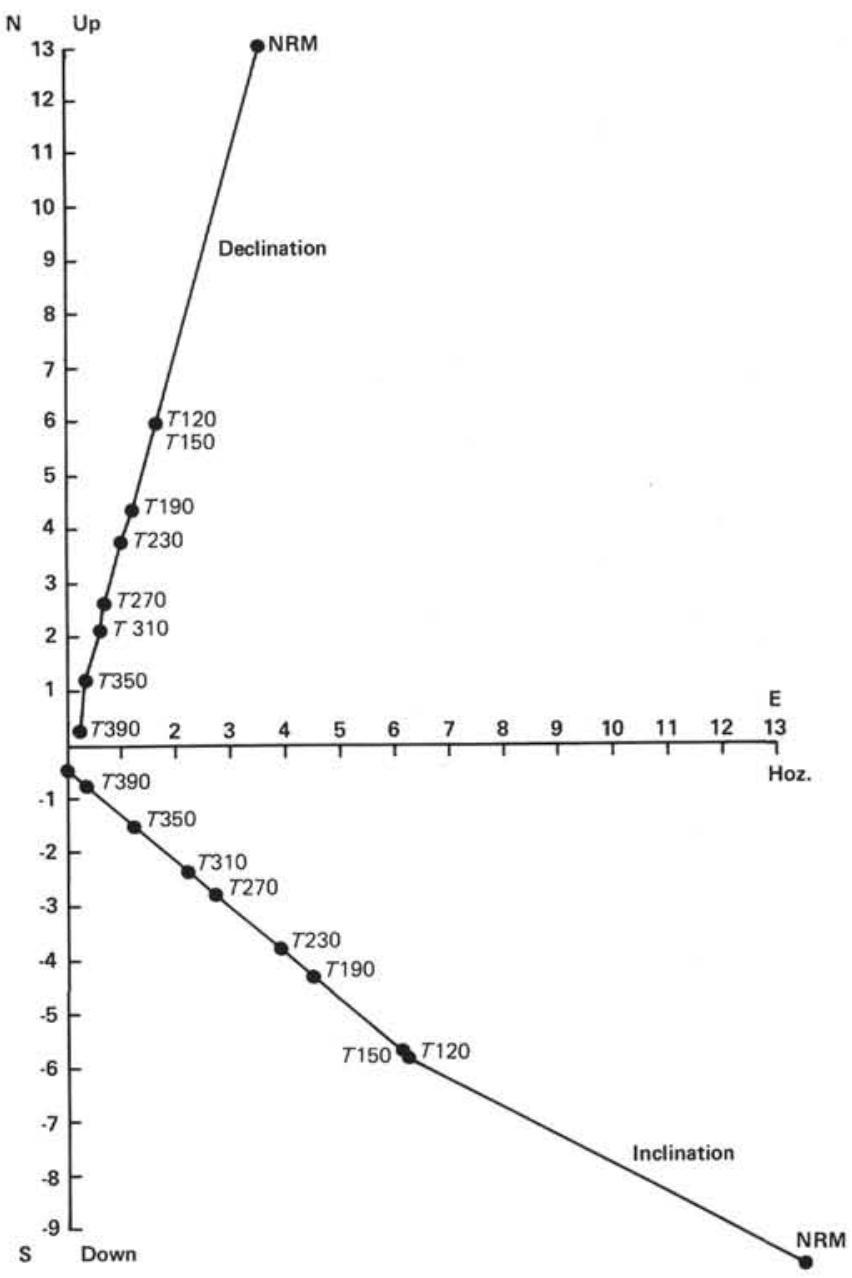

Figure 1. Thermal demagnetization of a typical sample of dusky red silty marl (Sample 534A-127-1, $92 \mathrm{~cm}$; middle to late Callovian). (A stable direction $\left[16^{\circ}\right.$ declination, $44^{\circ}$ inclination] is maintained during the rapid decrease in intensity until $390^{\circ} \mathrm{C}$. At higher temperatures (not shown), a near-antipodal direction $\left[192^{\circ}\right.$ declination, $14^{\circ}$ inclination] is observed and remains through the $620^{\circ} \mathrm{C}$ step. In this range $\left[430^{\circ}-620^{\circ} \mathrm{C}\right]$ the intensity remains at $1-2 \%$ of NRM intensity. $T 200$ is $200^{\circ} \mathrm{C}$. Declination [N, E, S] is on the same scale [1 div. $=10^{-5} \mathrm{emu} / \mathrm{cm}^{3}$ ) as inclination [Up, Hoz., Down].) 
played an apparent reversed polarity above $420^{\circ} \mathrm{C}$ ). This high stability to alternating fields and rapid drop in intensity at low temperatures suggest the presence of goethite, very fine-grained hematite, or titanomagnetite. Considering the high percentage of $\mathrm{Fe}$ and $\mathrm{Ti}$ in these metalliferous sediments, high clay content, and red color (see Ogg et al., this volume), it is possible that all three are present. Several samples displayed a shift in direction above $350^{\circ}$ to $400^{\circ} \mathrm{C}$. In most cases, the direction of magnetization attained at $500^{\circ} \mathrm{C}$ remained constant upon heating above $570^{\circ} \mathrm{C}$, though intensity would often drop by another order of magnitude. This indicates that a hematite carrier is present, with perhaps also magnetite with a similar direction of magnetization. The inclinations of the four samples heated above $550^{\circ}$ range from $-6^{\circ}$ to $17^{\circ}$ at the highest steps $\left(570^{\circ}-670^{\circ}\right)$, but curiously the declinations converged to a nonrandom $197^{\circ}$ to $209^{\circ}$ cluster for three of these samples, which strongly suggests acquisition of a stable remanence induced during coring with the drill press. All these complications and the apparent presence of a variety of magnetic minerals led to the decision not to use these sediments for magnetostratigraphy.

Greenish black silty claystone and marly limestone turbidites (middle to late Callovian). The NRM inclinations of the greenish black carbonaceous clays average $55 \pm 5^{\circ}$ (one standard deviation), which is very near the present field inclination of $59^{\circ}$. AF demagnetization had a minor effect on the directions of magnetization, especially when compared to early stages of thermal demagnetization. Shallowing of the inclinations to an average of $20^{\circ}$ to $30^{\circ}$ was common above $350^{\circ} \mathrm{C}$ (Fig. 2), and possible reversals of direction were observed above $450^{\circ} \mathrm{C}$ in some cases. Intensities decrease from about 2 to $8 \times 10^{-6} \mathrm{emu} / \mathrm{cm}^{3}$ at NRM, to about 2 to $20 \times 10^{-7}$ at $300^{\circ} \mathrm{C}$. The behavior of the pilot samples was not sufficiently uniform to determine what magnetic minerals are carrying the magnetization, but titanomagnetite and pyrrhotite are probably both present in these Ti-rich, metalliferous, sulfide-bearing, carbonaceous claystones. Kligfield and Channell (1981) suggest that magnetite may be produced by the breakdown of $\mathrm{Fe}$-sulfides during thermal demagnetization above $350^{\circ}$ resulting in laboratory-induced magnetic properties. This may explain the unstable behavior above $500^{\circ} \mathrm{C}$ and the lack of stable reversed directions. All stable directions during progressive thermal demagnetization are of apparent normal polarity with a $20^{\circ}$ to $30^{\circ}$ inclination. It is not possible to determine if this is the paleofield during this period.

The intercalations of marly limestone turbidites display a fairly uniform behavior during demagnetization. The intensity of magnetization drops sharply during the early stages of thermal treatment from NRMs in the 10 to $20 \times 10^{-7} \mathrm{emu} / \mathrm{cm}^{3}$ range to about $30 \%$ of NRM intensity by $200^{\circ} \mathrm{C}$. Above $400^{\circ} \mathrm{C}$, many of the samples displayed instability in direction of magnetization, perhaps caused by the formation of other magnetic minerals as the Fe-sulfides or maghemites were broken down. Under progressive AF demagnetization, the samples had median destructive fields in the 250 - to 300 -Oe range,

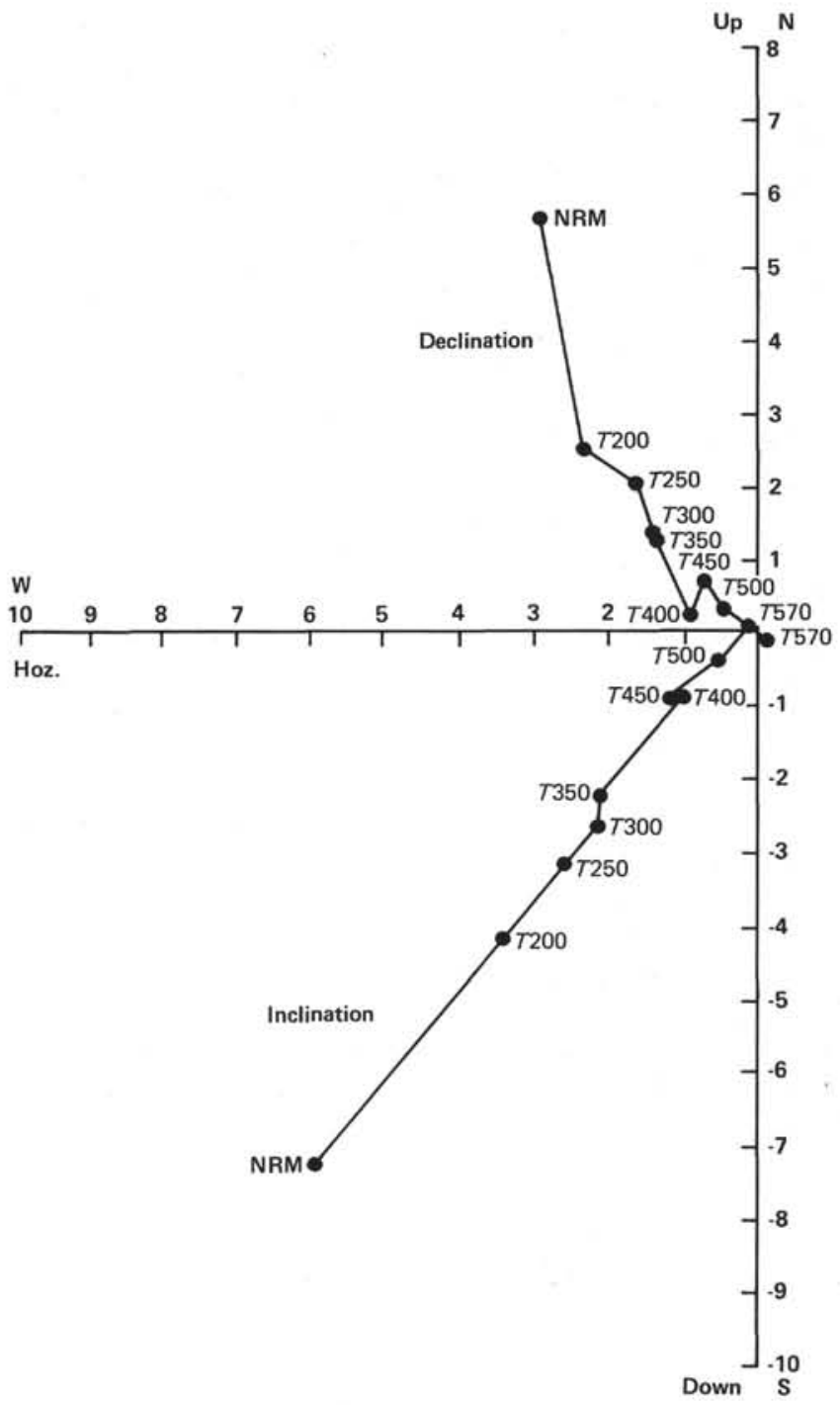

Figure 2. Thermal demagnetization of a typical sample of greenish black silty claystone $(534 \mathrm{~A}-125-1,124 \mathrm{~cm}$; middle to late Callovian). (The inclination shallows from $50^{\circ}$ at NRM to $38^{\circ}$ at the $450^{\circ} \mathrm{C}$ step while the declination rotates about $30^{\circ}$ counterclockwise. At $570^{\circ} \mathrm{C}$, an antipodal direction is present, but the intensity is only $8 \times 10^{-8} \mathrm{emu} / \mathrm{cm}^{3}, T 200$ is $200^{\circ} \mathrm{C}$. Declination [N, W, S] is on the same scale $\left[1 \mathrm{div} .=10^{-6} \mathrm{emu} / \mathrm{cm}^{3}\right]$ as inclination [Up, Hoz., Down].)

but intensity of magnetization usually fell by an order of magnitude between 350 and 500-Oe. NRM inclinations have a mean of $56^{\circ} \pm 8^{\circ}$, which probably is dominated by a present field component. During both progressive $\mathrm{AF}$ and early stages of thermal demagnetization, the inclinations would generally shallow. Because the directions generally continued to change, characteristic inclinations were rarely identifiable; but possible nearcharacteristic inclinations seemed to fall between $15^{\circ}$ and $30^{\circ}$ in the more stable samples. There were scattered samples achieving reversed inclinations or displaying a trend toward a reversed direction during the progressive demagnetization.

The behavior of the samples suggests that titanomagnetite and/or maghemite is the principle carrier of pri- 
mary magnetization and that a strong VRM of present field and/or drilling remanance is overprinted. The ancient field seems to have had mixed polarity. Some samples had a $30^{\circ}$ to $35^{\circ}$ decrease in declination accompanying the progressive shallowing of inclination during demagnetization. This suggests that the primary declination may lie near $325^{\circ}$ to $330^{\circ}$, if one interprets this counterclockwise motion with respect to the post-Callovian secondary magnetization as movement away from a present-day field overprint.

Recovery, sampling density, and percentage of results interpretable for polarity were all inadequate to determine a magnetostratigraphy.

Variegated claystones (Oxfordian). Between Cores 111 and 121 recovery was less than $15 \%$ of the cored section. This low recovery discouraged efforts at magnetostratigraphy, and only a few samples were analyzed.

NRM intensities ranged from 2 to $54 \times 10^{-7} \mathrm{emu} /$ $\mathrm{cm}^{3}$ and exhibited no obvious correlations with facies, color, or meter level of samples. NRM inclinations ranged from $80^{\circ}$ to $-22^{\circ}$. The progressive thermal demagnetization of a gray claystone sample (534A-112-1, $13 \mathrm{~cm}$ ) is shown in Figure 3 and is typical of the majority of the samples. The intensity decreases rapidly and at $200^{\circ} \mathrm{C}$ was typically less than $40 \%$ of the NRM intensity. For samples with reversed polarity (as in Fig. 3), a normal overprint, probably of the present-day field, is progressively removed through $400^{\circ} \mathrm{C}$. The direction at $400^{\circ} \mathrm{C}$ appears to be stable through $620^{\circ} \mathrm{C}$, however, only one sample was heated to this temperature. At $500^{\circ} \mathrm{C}$, the average intensity was $3 \times 10^{-7} \mathrm{emu} / \mathrm{cm}^{3}$ or less. More detailed work is necessary to determine the components and carriers of the magnetic remanence, but the stable remanence above $400^{\circ} \mathrm{C}$ appears to be carried by magnetite and/or fine-grained hematite.

Six of the samples had definite reversed polarity (the more stable inclinations were $-24^{\circ}$ to $\left.-33^{\circ}\right), 4$ samples had definite normal polarity $\left(23^{\circ}\right.$ to $\left.34^{\circ}\right)$, and 7 did not attain a stable direction by $500^{\circ} \mathrm{C}$ but the probable polarity could generally be determined. The polarity stratigraphy indicates a minimum of 5 reversed and 4 normal zones within this interval. The mean stable inclination is about $24^{\circ} \pm 8^{\circ}$.

Greenish gray marl and calciturbidites (Kimmeridgian-?Oxfordian). The sediments recovered between Cores 110 and 103 were dominated by calcareous turbidites, and the majority of the samples are from these beds. The host (greenish gray) claystones and marls were less cohesive, and minicores were collected only in the few reddish brown horizons that were more cohesive. A total of 27 samples was analyzed.

The NRM intensities of the limestone turbidites were typically only 1 to $4 \times 10^{-7} \mathrm{emu} / \mathrm{cm}^{3}$, and the NRM inclinations were positive in all but three samples. Upon heating $\left(200^{\circ} \mathrm{C}\right)$, nearly every sample displayed negative inclinations, and reversed directions were generally stable at the $200^{\circ} \mathrm{C}$ to $400^{\circ} \mathrm{C}$ demagnetization steps. Over

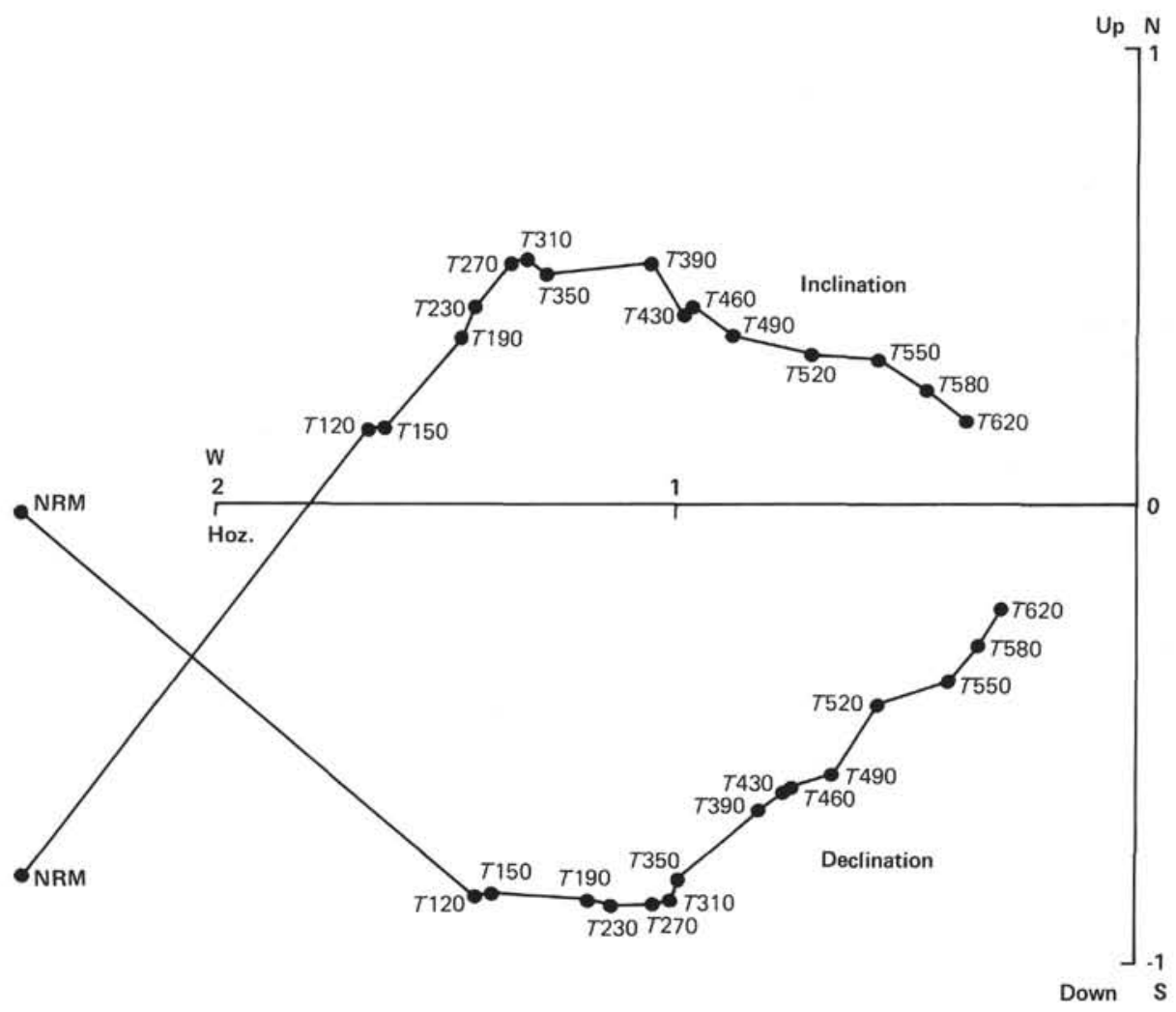

Figure 3. Thermal demagnetization of a typical sample of variegated claystone (Sample 534A-112-1, $13 \mathrm{~cm}$; Oxfordian). (A stable reversed-polarity direction is present above $350^{\circ} \mathrm{C}$ and is maintained through $620^{\circ} \mathrm{C} .1$ div. $=10^{-6} \mathrm{emu} / \mathrm{cm}^{3}$.) 
this interval the intensities slowly decreased, and no samples were heated beyond $500^{\circ} \mathrm{C}$. The NRM intensities of the red marls were much greater $\left(4\right.$ to $11 \times 10^{-6}$ $\mathrm{emu} / \mathrm{cm}^{3}$ ), and stable characteristic directions were usually not obtained until thermal demagnetization above $300^{\circ} \mathrm{C}$. In two curious cases, the apparent overprint removed between the NRM and the $300^{\circ} \mathrm{C}$ steps was of negative inclination. The intensity at $620^{\circ}$ is typically over $50 \%$ of the intensity at the $300^{\circ} \mathrm{C}$ step, indicating that hematite is an important magnetic carrier.

The mean inclinations are $-28^{\circ} \pm 9^{\circ}$ for reversed samples $(N=18)$ and $25^{\circ} \pm 11^{\circ}(N=5)$ for normal samples (using the $350^{\circ} \mathrm{C}$ step for the limestone turbidites, the $400^{\circ}$ step for the red marls, and rejecting samples that did not yet show a stable direction). The weighted average is about $27^{\circ} \pm 9^{\circ}$.

Grayish red marl and marly limestone (Tithonian?Kimmeridgian). Over 80 samples of the red marl unit (Cores 103 to 92, Section 2) were analyzed. The NRM intensity was normally in the 0.7 to $2.5 \times 10^{-6} \mathrm{emu} / \mathrm{cm}^{3}$ range, and the NRM inclination was generally between $30^{\circ}$ and $50^{\circ}$. Only 4 of the eighty NRM inclinations were negative. AF demagnetization had a negligible effect on both the intensity and direction of magnetization (although one of the pilots did exhibit a shift to negative inclination above $500 \mathrm{Oe}$ ).

The effects of thermal demagnetization are dramatic. Figure 4 shows the progressive thermal demagnetization of a sample with reversed characteristic polarity. The normal overprint, which dominates the NRM, is removed above $350^{\circ} \mathrm{C}$, and there is a stable reversed direction maintained from $400^{\circ}$ through $620^{\circ} \mathrm{C}$. Samples with normal polarity displayed a shallowing of inclination between $200^{\circ}$ and $350^{\circ} \mathrm{C}$, generally accompanied by a $10^{\circ}$ to $20^{\circ}$ counterclockwise shift of the declination. Progressive AF demagnetization through $700 \mathrm{Oe}$ after a sample had been heated to $300^{\circ} \mathrm{C}$ had an insignificant effect. Therefore, the characteristic magnetization must be carried by hematite. Steiner (1977) observed the same behavior in the similar Upper Jurassic red marl unit at Site 105 (about $800 \mathrm{~km}$ to the northnortheast of Site 534) and, on the basis of more extensive studies of the magnetic properties, concluded that the secondary component is perhaps carried by an oxidized titanomagnetite, with possibly titanomagnetite and pyrrhotite also present.

The mean inclination is $27^{\circ} \pm 8^{\circ}$ for normal polarity samples $(N=53)$ and $-25^{\circ} \pm 5^{\circ}(N=14)$ for reversed polarity samples (at the $400^{\circ} \mathrm{C}$ step, rejecting samples which had not attained a consistent direction).

White limestone (Berriasian). A total of 85 samples were analyzed from the white limestone unit between Cores 82 and 92, Section 1. NRM intensities are generally in the 2 to $7 \times 10^{-7} \mathrm{emu} / \mathrm{cm}^{3}$ range, with higher values just above the Tithonian red marl unit and in a reddish brown horizon in Core 83. NRM inclinations are usually between $40^{\circ}$ and $60^{\circ}$, and only 4 samples had negative inclinations.

Progressive AF demagnetization caused a rapid decrease in intensity but affected the direction of magnetization very little. Figure 5A illustrates the behavior of a

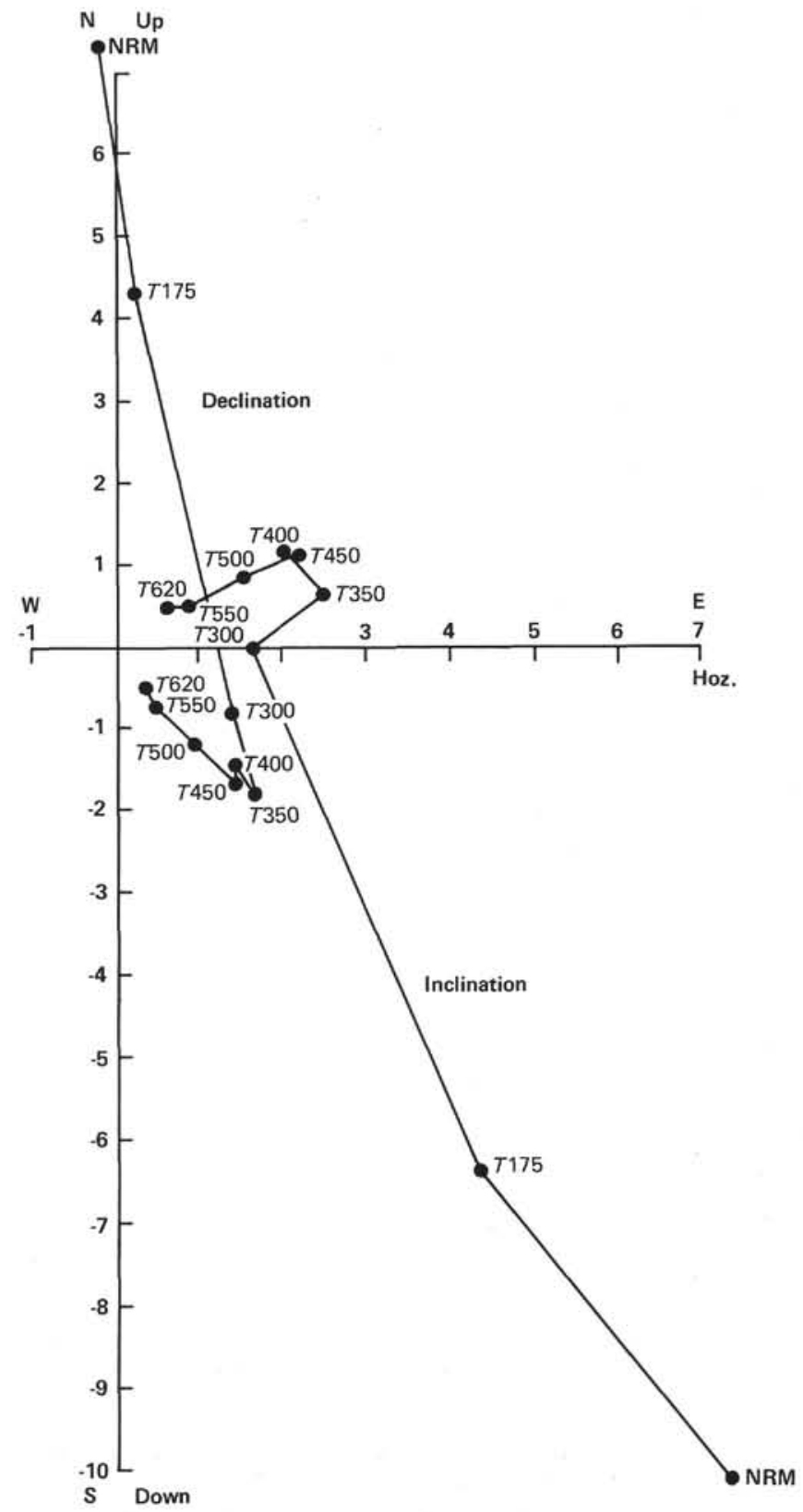

Figure 4. Thermal demagnetization of a typical sample of red marl (534A-94-3, $46 \mathrm{~cm}$; Tithonian). (A stable reversed polarity direction is present above $350^{\circ} \mathrm{C}$ and is maintained through $620^{\circ} \mathrm{C} .1$ div. $=10^{-7} \mathrm{emu} / \mathrm{cm}^{3}$.)

typical sample-the intensity of $3 \times 10^{-8} \mathrm{emu} / \mathrm{cm}^{3}$ at the $250-O e$ step is only $10 \%$ of the NRM intensity. However, the limestones had blocking temperatures of between 200 and $300^{\circ} \mathrm{C}$ and stable characteristic directions between $300^{\circ}$ and $450^{\circ}$ to $500^{\circ} \mathrm{C}$. This is illustrated in Figure 5B by the appearance of a reversed polarity at $300^{\circ} \mathrm{C}$ in the adjacent half-core of Section 534A-90-2, $37 \mathrm{~cm}$. The blocking temperature was lower in the upper part of the unit, but the lower intensities of these samples prohibited meaningful analysis above the $300^{\circ} \mathrm{C}$ step in most cases. In addition, these upper samples often displayed unstable directions after the $400^{\circ} \mathrm{C}$ step. A possible explanation for these magnetic properties 

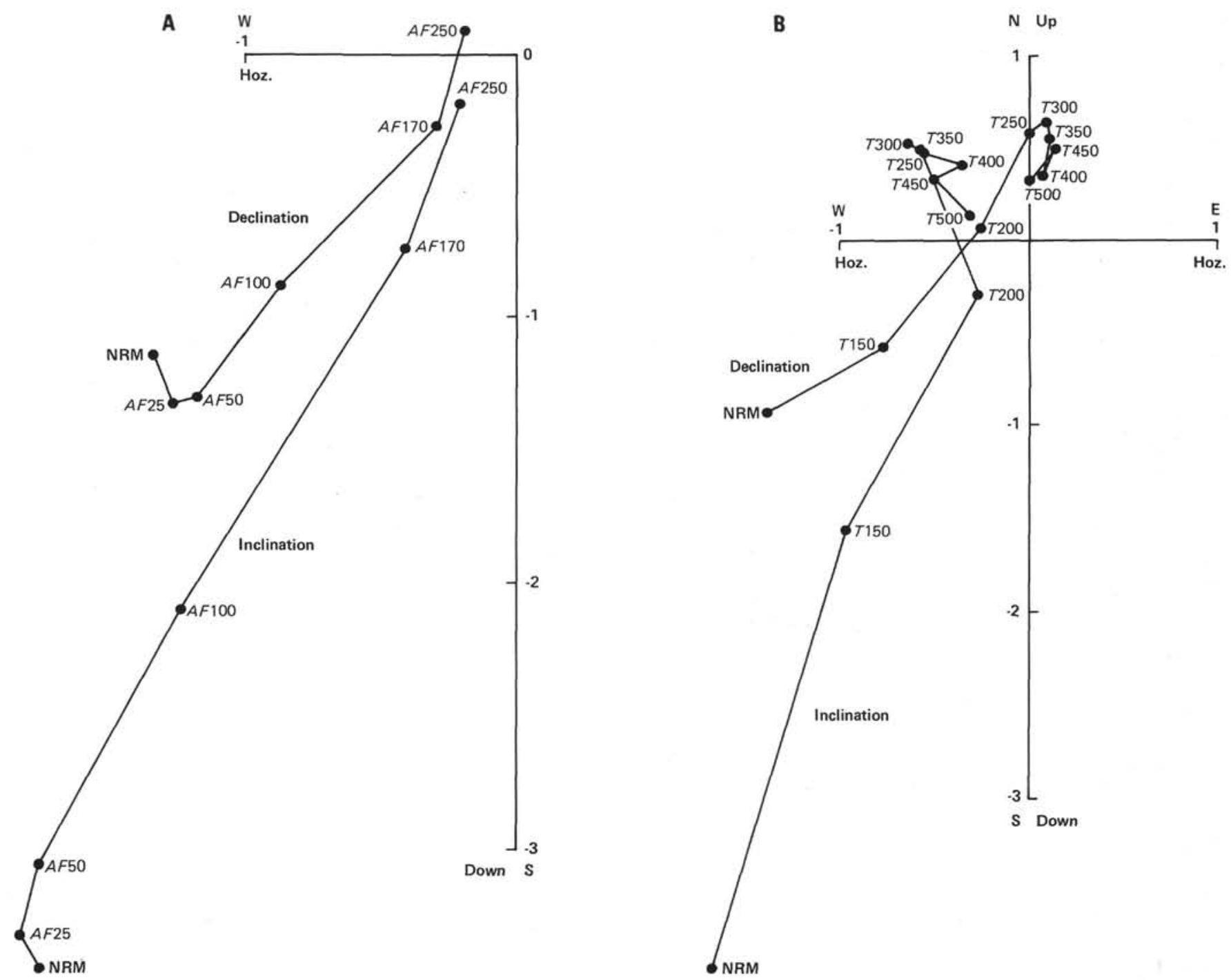

Figure 5. A. AF and B. thermal demagnetization of a split sample of white limestone (534A-90-2, $37 \mathrm{~cm}$; Berriasian/Tithonian boundary). (Thermal treatment above $300^{\circ} \mathrm{C}$ reveals a stable reversed-polarity component that is not apparent with $\mathrm{AF}$ treatment. 1 div. $=10^{-7} \mathrm{emu} / \mathrm{cm}^{3}$.)

is a primary magnetization carried by magnetite and a stronger secondary normal polarity carried by goethite and/or oxidized titanomagnetite and/or pyrrhotite. Hematite, the primary carrier in the underlying red unit, could not be demonstrated due to the extremely low intensities above $500^{\circ} \mathrm{C}$ but probably is not present in these relatively reduced sediments.

The mean inclinations are $36.1^{\circ} \pm 6.2^{\circ}$ for the normal polarity samples $(N=36)$ and $-37.1^{\circ} \pm 7.2^{\circ}(N=$ 42) for the reversed polarity samples (the selected values and demagnetization steps are in the Appendix; samples with uncertain polarity were omitted). Normal polarity samples also commonly exhibited a $10^{\circ}$ to $20^{\circ}$ counterclockwise shift in the declination as the normal overprint was removed.

Laminated limestones (early Valanginian). Six cores (76-81) of gray laminated limestones were sampled in 38 horizons. The NRM intensities are generally in the 3 to $10 \times 10^{-8} \mathrm{emu} / \mathrm{cm}^{3}$, and nearly all NRM inclinations were between $30^{\circ}$ and $60^{\circ}$. AF demagnetization had negligible effect on the directions at low steps (to 170
Oe) while reducing the intensities by 30 to $50 \%$. Thermal demagnetization at low temperatures $\left(120^{\circ}-200^{\circ} \mathrm{C}\right)$ generally resulted in a shallowing of the inclinations. At the $250^{\circ} \mathrm{C}$ step, half of the samples had intensities below $1 \times 10^{-8} \mathrm{emu} / \mathrm{cm}^{3}$. At higher thermal steps, most samples became highly susceptible and very quickly acquired spurious magnetizations even in the low-field (2000 gammas) measuring area. This laboratory-acquired component dominated the weak magnetization at the $400^{\circ}$ step.

Reversed polarity was apparent only in four samples and indicated by the demagnetization behavior of three others. The laminated limestone appears to be predominantly of normal polarity, but further analysis is required. Stable or consistent directions in these weak samples were rare and so no mean inclination was calculated.

Upper units (Hauterivian-Valanginian). Pilot samples were analyzed from 27 horizons between Cores 49 and 75 . The lithologies were mainly laminated gray marly limestone or bioturbated light gray limestone, but 
three gray calcareous turbidite beds were also analyzed. Only progressive AF demagnetization through $100 \mathrm{Oe}$ and thermal demagnetization through $400^{\circ} \mathrm{C}$ have been done at present. NRM intensities generally ranged from 3 to $7 \times 10^{-8} \mathrm{emu} / \mathrm{cm}^{3}$ and all NRM inclinations were positive. AF demagnetization to 100 Oe generally resulted in a 40 to $50 \%$ decrease in intensities accompanied by small shifts in direction. Sharp drops in the intensities usually occurred upon $120^{\circ} \mathrm{C}$ thermal demagnetization, and the majority of the samples were below $2 \times 10^{-8}$ $\mathrm{emu} / \mathrm{cm}^{3}$ at the $150^{\circ} \mathrm{C}$ step. Reversed polarity was apparent in only 3 samples and suspected in the behavior of 3 others. The calcareous turbidites had very stable normal inclinations $\left(36 \pm 2^{\circ}, N=3\right)$ throughout demagnetization. No significant difference in either the intensities or demagnetization behavior was noticed between laminated or bioturbated limestones.

\section{MAGNETOSTRATIGRAPHY}

The Kimmeridgian through lower Valanginian sediments of Cores 108 through $76(270 \mathrm{~m})$ yielded a fairly complete polarity sequence. The inclinations and intensity of the characteristic directions (tabulated in the Appendix with the demagnetization level) are graphed in Figure 6 with the interpretation of polarity zones. Gaps in recovery or inconclusive characteristic polarities are indicated by a cross-hatch pattern, and if a polarity is indicated by only a single sample, a partial bar is used.

The proposed correlation to the magnetic polarity pattern of the Kimmeridgian-Tithonian-Berriasian (Ogg, 1981; Ogg et al., unpublished data) and to the marine magnetic anomaly M-sequence (Larson and Hilde, 1975) is shown in Figure 7. The correlation in the Tithonian and Berriasian is excellent. Some observations are:

(1) The sudden change between Berriasian white homogenous limestones and Valanginian gray laminated limestones corresponds to marine seismic reflector ' ${ }^{\prime}$ and indicates a possible hiatus (see Sheridan et al., this volume). Therefore, the apparent predominantly normal polarity interval of the early Valanginian at Site 534 could correlate either to the normal zone between M-15 and $\mathrm{M}-16$ or to the normal zone above M-15.

(2) The definition of the Tithonian/Berriasian boundary is not yet fixed. One proposed definition is the sudden increase in abundance of the nannofossil Nannoconus colomi (Thierstein, 1975). This increase occurs within the lower portion of the normal polarity zone between "M-18" and "M-17" ("FG-3N") or near the top of "M18 " ("FG-3R") in the Italian sections (technically, the terminology in parentheses should be used for labeling polarity zones after their identification in stratigraphic sections [see IUGS International Subcommission on Stratigraphic Classification, 1979]). At Site 534, this event occurs earlier, at the base of Core 91 (Roth et al., this volume) or the top of the normal polarity interval below "M-18." The palynological definition of the Tithonian/ Berriasian boundary places it within the lower part of Core 90, hence within "M-18." These different assignments vary by less than a half million years and could be reconciled in several ways: (1) Nannoconus colomi be- came abundant in the Atlantic earlier than in the Tethys Ocean; (2) the delay between the deposition of sediment and the fixing of the primary magnetization below the level of active bioturbation (Kent, 1973; Verosub, 1977; Ellwood, 1979) implies that the much higher sedimentation rate at Site 534 yielded a fixing of magnetization more synchronous with deposition than in the more condensed sections of northern Italy, hence the Tithonian/ Berriasian boundary is at the base of "M-18" at Site 534 and the top of "M-18" in northern Italy (where "M-18" $=$ "FG-3R" is only $1.1 \mathrm{~m}$ thick); or (3) both of these.

(3) The correlation between the polarity sequence and the calpionellid zonation at Site 534 (Remane, this volume) agrees with the correlation of polarity zones and calpionellid zones in northern Italy. Calpionellid Zone $\mathrm{C}$ has not been identified in the Atlantic; the polarity sequence correlation implies that it should begin above Core 86.

(4) "M-21"' (or "FG-7R") was not identified at Site 534 , but a $13-\mathrm{m}$ gap in recovery spans the interval within which it should occur (assuming relatively constant sedimentation).

(5) Between Cores 103 and 104 is a sudden change in sediment facies from red marl to greenish gray marl with abundant limestone turbidites. This change corresponds to marine seismic reflector D' (Sheridan et al., this volume), and an hiatus is probably present. The underlying greenish gray marl unit probably had a relatively rapid net sedimentation rate due to the input of turbidites, hence the apparently long reversed polarity interval may span a relatively short period of time. This reversed polarity zone may correlate to either "M-23" or "M-24" - probably the latter, considering the hiatus at the top of the unit.

(6) The carrier of the characteristic magnetization in the red marls is hematite. Channell et al. (1982) found that the formation and magnetization of diagenetic hematite in a red pelagic limestone unit in Italy occurred later than the magnetization carried by magnetite by less than $60 \mathrm{~cm}$ (after compaction) or about 100,000 yr. in those particular sediments, with the first diagenetic growth through the single-domain critical volume occurring prior to the fixation of magnetite. If this is valid for the red pelagic carbonates at Site 534 as well, then the magnetostratigraphy is probably offset by less than a meter from the biostratigraphy.

(7) The magnetostratigraphy obtained by Keating and Helsley (1978) in the Tithonian red marls and Berriasian limestones at nearby Site 391 cannot be correlated to the polarity sequence at Site 534 because of the different techniques of demagnetization (AF demagnetization is less effective in removing the normal overprint). Steiner (1977) used a similar thermal demagnetization method on the Upper Jurassic red marls at Site 105; this allows partial correlation to that polarity sequence. Site 105 was drilled between marine magnetic anomalies $\mathbf{M}-25$ and M-24; therefore, the oldest sediments should be earliest Kimmeridgian. Cores $\mathbf{3 7}$ through $\mathbf{4 0}$ have pelagic bivalve filaments, but no Saccocoma, whereas Cores 33 to 36 are a Saccocoma facies. In the Italian sections used for magnetostratigraphy, pelagic bivalve filaments are 


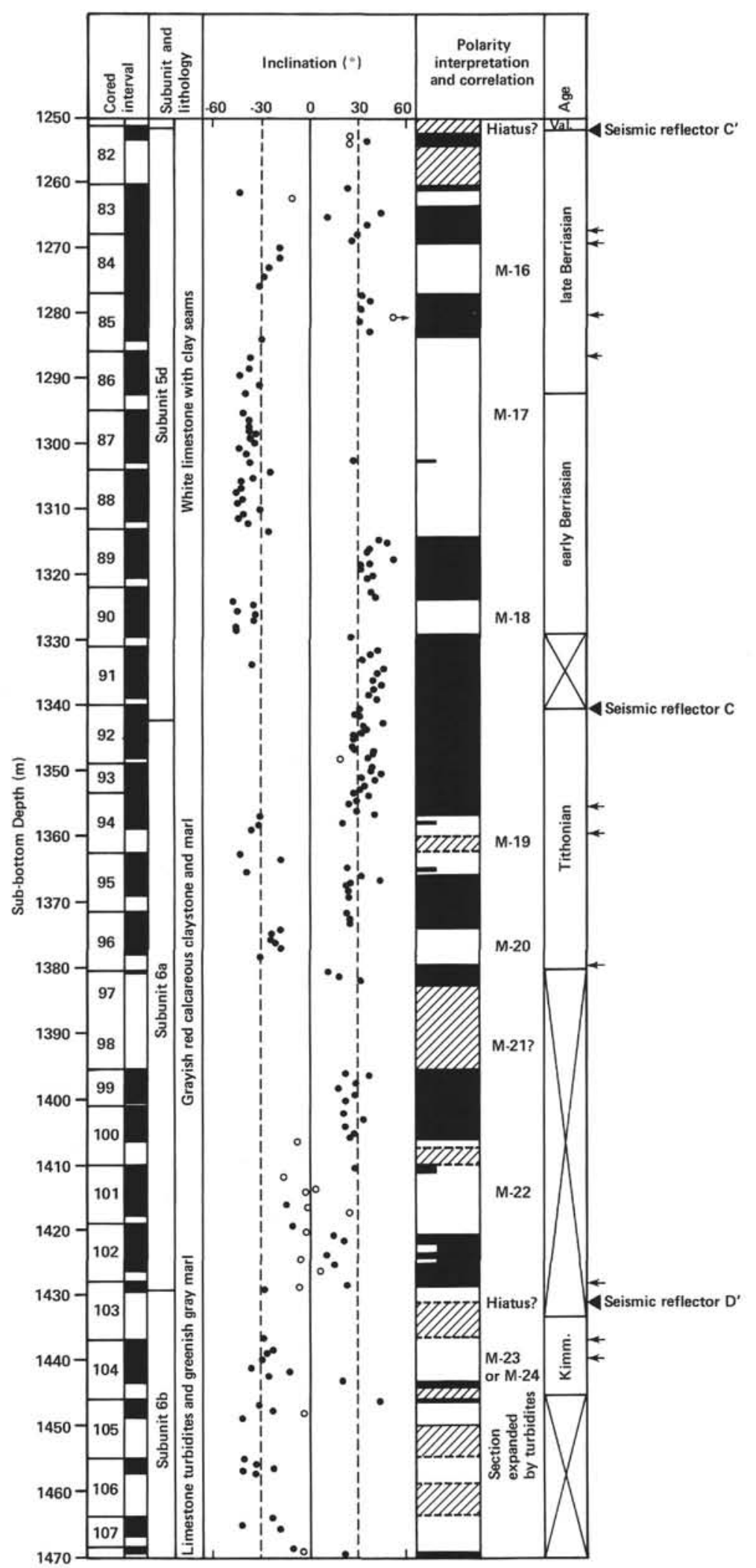

Figure 6. Magnetostratigraphy of Kimmeridgian-Tithonian-Berriasian sediments of Site 534. (Inclinations are characteristic directions during demagnetization or inclination of selected best demagnetization step [tabulated in the Appendix] and are shown as open circles if a reliable value was not attained. Polarity interpretations are based on the sample behavior during progressive demagnetization [black areas are normal]. If a possible polarity zone is represented by only a single core, it is shown as a partial bar. Chronostratigraphy is from Gradstein [this volume]. M-sequence correlations are shown in Fig. 7.) 


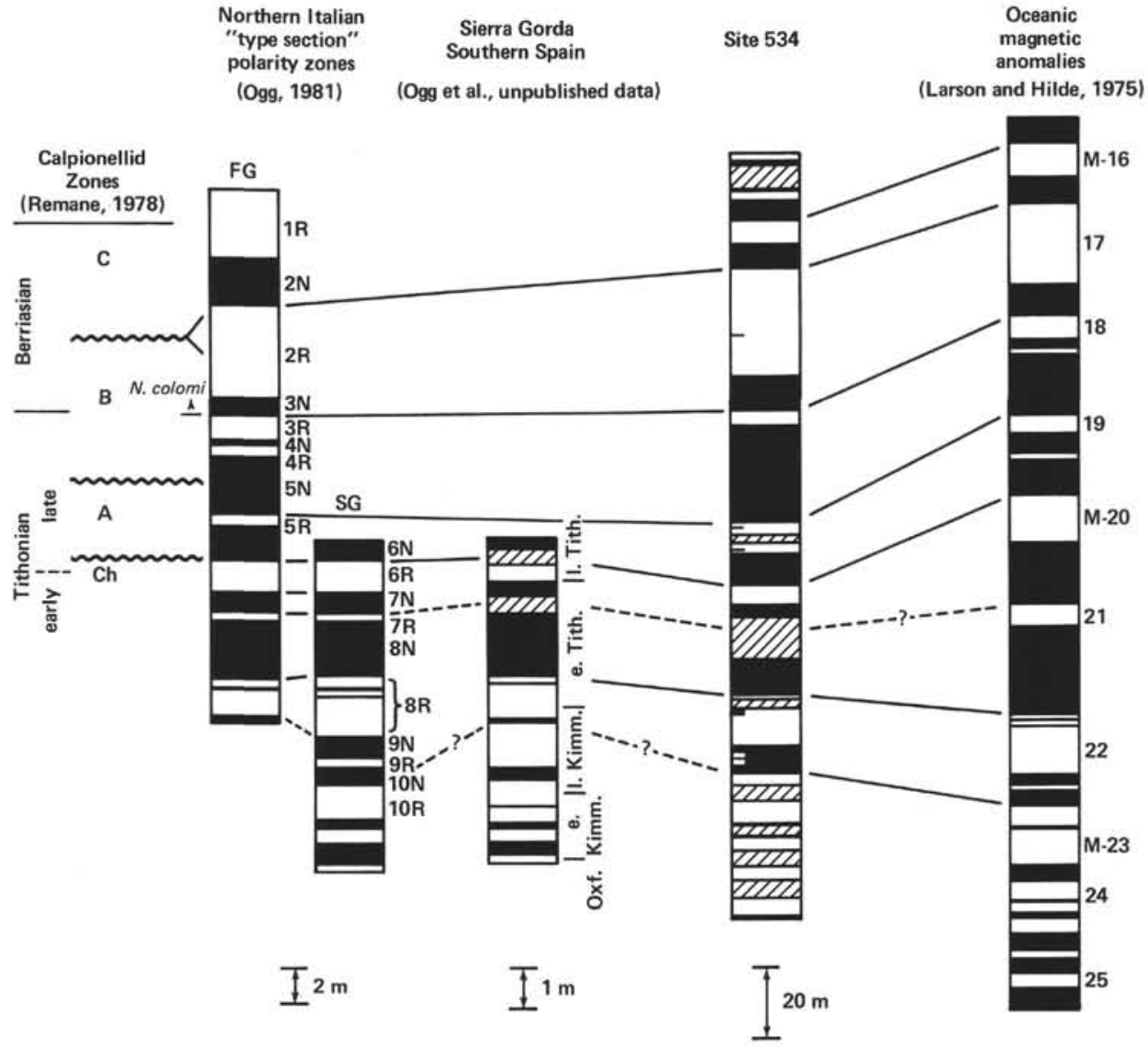

Figure 7. Proposed magnetostratigraphic correlations of Site 534 to polarity sequences of northern Italy (Ogg, 1981) and southern Spain (Ogg et al., unpublished data) and to the marine magnetic anomaly M-sequence (Larson and Hilde, 1975; Vogt and Einwich, 1979). (No adjustments have been made for differential sedimentation rates or seafloor spreading rates; a meter scale is shown for each section. Biostratigraphy is based on calpionellids and nannofossils for northern Italian selected "type sections" and on ammonite zones for the southern Spain section. No polarity zone correlations are attempted for Site 534 below "M-22" due to a probable hiatus in sedimentation.)

rarely significant above "M-22" and Saccocoma occurs mainly between "M-22"' and "M-19." Using these constraints, possible assignments of "M-24" and "M-23" can be given to the predominately reversed polarity zones of Cores 37 to 40 (hence, a Kimmeridgian age based on the magnetostratigraphy of that stage in southern Spain). The polarity pattern in the upper portion of Site 105 red marls (Cores 33-36) resembles the "M-20" to "M-22"' sequence. The Tithonian/Berriasian boundary (defined by nannofossils) in the upper portion of Core 33 at Site 105 is possibly an unconformity corresponding to the change from red to white sediments (Thierstein, 1975; Wind, 1978) and recovery was poor; therefore, further assignments are not attempted. If this correlation is valid, then the apparent major hiatus in the Kimmeridgian at Site 534 (encompassing "'M-23'”) is less important at Site 105. This is consistent with the nannofossil biostratigraphy of Wind (1978).

(8) The red to white limestone transition at the end of the Jurassic is a general feature in both Atlantic and Tethyan pelagic sediments. At Site 534 this occurs midway between "M-19"' and "M-18," whereas in the northern Italian sections, it occurs just above "M-20."

\section{APPARENT PLATE MOTION}

Mean inclinations of magnetization and $95 \%$ confidence limits on the means were computed using the statistical procedure of Kono (1980). The characteristic inclinations or best direction of each sample and the associated demagnetization step are compiled in the Appendix. Samples having intensities less than $2 \times 10^{-8}$ $\mathrm{emu} / \mathrm{cm}^{3}$ or having unstable or uncertain inclinations (denoted by "?" in the Appendix) were omitted. Equal weight was given to each sample, rather than averaging the two means of separate polarities. The mean inclinations of the five sediment units are shown in Table 1 . Drill string deviation from the vertical was less than $1.5^{\circ}$.

The results suggest either a stationary or slight northward movement of the Site between the Oxfordian and Tithonian. This was followed by apparent rapid northward movement of $6.0^{\circ} \pm 2.7^{\circ}$ during the Tithonian and Berriasian, implying a northward rate of movement in excess of $5 \mathrm{~cm} / \mathrm{yr}$. Such a rapid rate of movement has not yet been verified by examining other sites, therefore the reliability, hence significance, is uncertain. 
Table 1. Mean inclinations, Site 534.

\begin{tabular}{|c|c|c|c|c|c|c|c|}
\hline Sediment unit & Age & $N$ & k & $\begin{array}{c}\text { Mean } \\
\text { inclination } \\
\left({ }^{\circ}\right)\end{array}$ & $\alpha 95\left(^{\circ}\right)$ & $\begin{array}{l}\text { Paleolat } \\
\left({ }^{\circ}\right)\end{array}$ & $\begin{array}{l}\text { itude }{ }^{\circ} \mathrm{N} \\
(\alpha 95)\end{array}$ \\
\hline $\begin{array}{l}\text { Marly limestone } \\
\text { turbidites }\end{array}$ & $\begin{array}{l}\text { late Cal- } \\
\quad \text { lovian }\end{array}$ & 9 & 70 & $27.7^{\mathrm{a}}$ & 5.9 & $14.7^{\mathrm{a}}$ & $\left(3.5^{\circ}\right)^{\mathrm{a}}$ \\
\hline Variegated claystone & Oxfordian & 8 & 50 & 23.8 & 7.6 & 12.4 & $\left(4.3^{\circ}\right)$ \\
\hline $\begin{array}{l}\text { Greenish gray marl } \\
\text { and calciturbi- } \\
\text { dites }\end{array}$ & Oxf.-Kimm. & 23 & 40 & 27.7 & 4.9 & 14.7 & $\left(2.9^{\circ}\right)$ \\
\hline Grayish red marl & Kimm.-Tith. & 67 & 52 & 27.6 & 2.4 & 14.6 & $\left(1.4^{\circ}\right)$ \\
\hline White limestone & Berriasian & 78 & 70 & 36.9 & 1.9 & 20.6 & $\left(1.3^{\circ}\right)$ \\
\hline
\end{tabular}

Note: $N=$ no. of samples; $\mathrm{k}=$ dispersion parameter; $\alpha 95$ indicates the $95 \%$ confidence level. a May be tilted or slumped slightly in lower part; unreliable value.

The calculated paleolatitude of $14.6^{\circ} \mathrm{N} \pm 2^{\circ}$ for the Tithonian is shallower than the Kimmeridgian-Tithonian value of $24^{\circ} \mathrm{N} \pm 4^{\circ}$ calculated from the Mesozoic polar wander path of North America (Steiner, in press). There are no Lower Cretaceous poles for North America, and the Berriasian value of $20.6^{\circ} \mathrm{N} \pm 1.3^{\circ}$ obtained at Site 534 implies that a significant portion of the net northward motion of North America in the Cretaceous may have occurred early in that period. The estimated $12^{\circ} \mathrm{N} \pm 4^{\circ}$ paleolatitude for the Oxfordian is similar to the $9^{\circ} \mathrm{N} \pm 4^{\circ}$ calculated from Steiner (in press) for the Callovian-early Oxfordian.

An apparent $20^{\circ}$ to $30^{\circ}$ counterclockwise rotation between the Jurassic normal direction and the later normal overprint (present field) is observed in numerous samples, suggesting that the Site has rotated by at least this amount.

\section{SUMMARY}

Of the several sedimentary units composing the Late Jurassic and early Cretaceous sections of Site 534, adequate recovery and stable characteristic magnetizations occurred together only in the upper portion of the Kimmeridgian greenish gray marls and calcareous turbidites unit, the Tithonian red marl unit, and the Berriasian white limestone unit. The magnetostratigraphy of this interval correlates with co-eval sections in northern Italy and southern Spain and to M-16 through M-22 of the marine magnetic anomaly $\mathrm{M}$-sequence. This enables definition of the Berriasian/Tithonian magnetic boundary as within Core 90 , the late/early Tithonian boundary as the base of Core 96, and the Tithonian/Kimmeridgian boundary as the top of Core 102. The underlying Oxfordian variegated claystones and the middle to late Callovian sediments indicated mixed polarity through this interval, but recovery was inadequate to define polarity zones. The basal metalliferous sediments had multicomponent magnetizations, and determination of characteristic directions was difficult. The site had an apparent $6^{\circ}$ northward component of plate motion between the mean Tithonian and Berriasian directions, and a stationary or slight northward motion between the Callovian and Tithonian.

\section{ACKNOWLEDGMENTS}

This project was partially supported by the Deep Sea Drilling Project and partially by NSF Grant EAR81-07739 for Jurassic magnetostratigraphy. The scientific party and technical staff on Leg 76 aided the extensive sampling. Dr. David Van Alstine, Dr. Eugene Shoemaker, and Sierra Geophysics, Inc. provided use of their cryogenic magnetometer facilities at the California Institute of Technology. Drs. Maureen Steiner and Peter Shive provided support at the University of Wyoming cryogenic magnetometer facility, and Dr. Steiner reveiwed the manuscript and made numerous, valuable suggestions.

\section{REFERENCES}

Bryan, G. M., Markl, R. G., and Sheridan, R. E., 1980. IPOD site surveys in the Blake-Bahama Basin. Mar. Geol., 35:43-63.

Channell, J. E. T., Freeman, R., Heller, F., and Lowrie, W., 1982. Timing of diagenetic hematite growth in red pelagic limestones from Gubbio (Italy). Earth Planet. Sci. Lett., 58:189-201.

Channell, J. E. T., Lowrie, W., and Medizza, R., 1977. Geomagnetic polarity during the Early Cretaceous from limestones in the Venetian (Southern) Alps. EOS Trans., Am Geophys. Union, 58:867. 1979. Middle and Early Cretaceous magnetic stratigraphy from the Cismon section, northern Italy. Earth Planet. Sci. Lett., 42:153-166.

Ellwood, B. B., 1979. Particle flocculation: one possible control on the magnetization of deep-sea sediments. Geophys. Res. Lett., 6: 237-240.

IUGS International Subcommission on Stratigraphic Classification and IUGS/IAGA Subcommission on a Magnetic Polarity Time Scale, 1979. Magnetostratigraphic polarity units-a supplementary chapter of the ISSC International Stratigraphic Guide. Geology, 7:578-583.

Keating, B. H., and Helsley, C. E., 1978. Paleomagnetic results from DSDP Hole 391C and the magnetostratigraphy of Cretaceous sediments from the Atlantic Ocean floor. In Benson, W. E. Sheridan, R. E., et al., Init. Repts. DSDP, 44:Washington (U.S. Govt. Printing Office), 523-528.

Kent, D. V., 1973. Post-depositional remanent magnetization in deepsea sediment. Nature, 246:32-34.

Kligfield, R., and Channell, J. E. T., 1981. Widespread remagnetization of Helvetic limestones. J. Geophys. Res., 86:1888-1900.

Kono, M., 1980. Statistics of paleomagnetic inclination data. J. Geophys. Res., 85:3878-3882.

Larson, R. L., and Hilde, T. W. C., 1975. A revised time scale of magnetic reversals for the Early Cretaceous, Late Jurassic. J. Geophys. Res., 80:2586-2594.

Ogg, J. G., 1980. Upper Jurassic magnetostratigraphy from Northern Italy. EOS Trans., Am. Geophys. Union, 61:216.

1981. Sedimentology and paleomagnetism of Jurassic pelagic limestones: "Ammonitico Rosso" facies [Ph.D. dissert.]. Scripps Institution of Oceanography, University of California, San Diego.

Steiner, M. B., 1977. Magnetization of Jurassic red deep-sea sediments in the Atlantic (DSDP Site 105). Earth Planet. Sci. Lett., 35:205-214.

$\longrightarrow$ in press. Mesozoic plate motions of North America. Rev. Geophys. Space Phys.

Thierstein, H. R., 1975. Calcareous nannoplankton biostratigraphy at the Jurassic-Cretaceous boundary. Colloque sur la limite Jurassique-Cretace, Mem. Bur. Rech. Geo. Min., 86:84-94.

Verosub, K. L., 1977. Depositional and post-depositional processes in the magnetization of sediments. Rev. Geophys. Space Phys., 15: 129-143.

Vogt, P. R., and Einwich, A. M., 1979. Magnetic anomalies and seafloor spreading in the western North Atlantic, and a revised calibration of the Keathley (M) geomagnetic reversal chronology. In Tucholke, B. E., Vogt, P. R., et al., Init. Repts. DSDP, 43: Washington (U.S. Govt. Printing Office), 857-876.

Wind, F. H., 1978. Western North Atlantic Upper Jurassic calcareous nannofossil biostratigraphy. In Benson, W. E., Sheridan, R. E., et al., Init. Repts. DSDP, 44: Washington (U.S. Govt. Printing Office), 761-771.

Date of Initial Recept: August 30, 1982 
APPENDIX

Characteristic Directions of Hole 534A Samples

\begin{tabular}{|c|c|c|c|}
\hline $\begin{array}{c}\text { Sample } \\
\text { (core-section, cm.) }\end{array}$ & $\begin{array}{l}\text { Inclination } \\
\left({ }^{\circ}\right)\end{array}$ & $\begin{array}{l}\text { Intensity } \\
\left(\mathrm{emu} / \mathrm{cm}^{3}\right)^{\mathrm{a}}\end{array}$ & $\begin{array}{l}\text { Demag step } \\
\left({ }^{\circ} \mathrm{C}\right)^{\text {b }}\end{array}$ \\
\hline $49-2,4$ & -50.0 & 5.6 E-9 & 350 \\
\hline $53-1,93$ & 35.7 & $1.3 \mathrm{E}-8$ & 300 \\
\hline $56-3,29$ & 40.6 & $6.9 \mathrm{E}-8$ & 300 \\
\hline $59-1,7$ & 38.5 & $5.2 \mathrm{E}-6$ & 300 \\
\hline $61-2,12$ & 33.0 & $4.3 \mathrm{E}-7$ & 300 \\
\hline $63-1,45$ & 19.2 & 9.5 E-6 & 300 \\
\hline $64-4,54$ & -55.0 & $1.9 \mathrm{E}-6$ & 250 \\
\hline $66-1,145$ & 43.3 & 5.0 E-8 & 300 \\
\hline $66-4,114$ & 31.3 & $1.0 \mathrm{E}-7$ & 300 \\
\hline $67-1,51$ & $-48.0 ?$ & $1.1 \mathrm{E}-8$ & 300 \\
\hline $67-3,33$ & $0.8 ?$ & 7.2 E-9 & 350 \\
\hline $68-1,111$ & $53.1 ?$ & 8.0 E-9 & 350 \\
\hline $68-4,14$ & 33.9 & $2.1 \mathrm{E}-8$ & 300 \\
\hline $69-1,29$ & 25.7 & $1.1 \mathrm{E}-8$ & 300 \\
\hline $69-5,101$ & 60.7 & $2.0 \mathrm{E}-8$ & 300 \\
\hline $70-1,118$ & 48.0 & $1.1 \mathrm{E}-8$ & 350 \\
\hline $70-5,69$ & $66.0 ?$ & $2.0 \mathrm{E}-8$ & 300 \\
\hline $71-3,99$ & $65.2 ?$ & $1.4 \mathrm{E}-8$ & 300 \\
\hline $71-4,30$ & 49.6 & 8.0 E-9 & 300 \\
\hline $72-1,83$ & 31.5 & 5.7 E-9 & 250 \\
\hline $72-5,118$ & 40.0 & 7.1 E-9 & 350 \\
\hline $73-1,11$ & $58.0 ?$ & $1.0 \mathrm{E}-8$ & 250 \\
\hline $73-4,35$ & 42.9 & 7.3 E-9 & 350 \\
\hline $74-2,126$ & 36.4 & $2.0 \mathrm{E}-8$ & 350 \\
\hline $74-6,78$ & $46.4 ?$ & $1.3 \mathrm{E}-8$ & 250 \\
\hline $75-3,99$ & -37.0 & 6.0 E-9 & 350 \\
\hline $75-6,45$ & $-21.6 ?$ & 3.1 E-9 & 350 \\
\hline $76-1,105$ & 57.1 & 8.5 E-9 & 250 \\
\hline $76-2,97$ & 28.6 & $3.3 \mathrm{E}-8$ & 250 \\
\hline $76-3,31$ & 52.0 & 6.6 E-9 & 300 \\
\hline $76-4,11$ & 29.1 & $2.2 \mathrm{E}-8$ & 250 \\
\hline $76-5,11$ & -60.1 & 9.2 E-9 & 450 \\
\hline $76-5,106$ & $25.3 ?$ & 4.0 E-9 & 250 \\
\hline $76-6,85$ & 31.2 & $5.9 \mathrm{E}-8$ & 250 \\
\hline $77-1,40$ & 27.5 & $6.6 \mathrm{E}-8$ & 250 \\
\hline $77-1,93$ & 29.2 & $1.9 \mathrm{E}-8$ & 250 \\
\hline $77-2,83$ & 32.1 & $2.0 \mathrm{E}-8$ & 250 \\
\hline $77-3,22$ & 43.6 & $1.4 \mathrm{E}-8$ & 300 \\
\hline $77-4,30$ & 41.6 & 3.4 E-8 & 250 \\
\hline $78-1,97$ & 34.7 & $8.6 \mathrm{E}-8$ & 250 \\
\hline $78-2,31$ & $-48.5 ?$ & $6.3 \mathrm{E}-9$ & 350 \\
\hline $78-2,109$ & $1.9 ?$ & 5.0 E-9 & 250 \\
\hline $78-3,21$ & -21.4 & $1.3 \mathrm{E}-8$ & 200 \\
\hline $78-3,130$ & 34.1 & 9.5 E-9 & 350 \\
\hline $78-4,38$ & $47.9 ?$ & $2.2 \mathrm{E}-8$ & 300 \\
\hline $78-4,140$ & 23.8 & $3.6 \mathrm{E}-8$ & 350 \\
\hline $78-5,45$ & 14.2 & $3.6 \mathrm{E}-8$ & 250 \\
\hline $78-6,10$ & 39.4 & 9.6 E-9 & 250 \\
\hline $79-1,8$ & 10.2 & $3.8 \mathrm{E}-8$ & 250 \\
\hline $79-2,25$ & 30.7 & $2.7 \mathrm{E}-8$ & 300 \\
\hline $79-3,43$ & $21.7 ?$ & 4.8 E-9 & 250 \\
\hline $79-4,52$ & $1.8 ?$ & $5.0 \mathrm{E}-7$ & 200 \\
\hline $79-4,136$ & 38.3 & $4.3 \mathrm{E}-8$ & 250 \\
\hline $79-6,45$ & $3.6 ?$ & 8.5 E-9 & 350 \\
\hline $80-1,120$ & $38.9 ?$ & 3.9 E-9 & 200 \\
\hline $80-2,89$ & 68.5 & $1.1 \mathrm{E}-8$ & 200 \\
\hline $80-3,14$ & 25.5 & $2.4 \mathrm{E}-8$ & 200 \\
\hline $80-3,138$ & -41.5 & $1.0 \mathrm{E}-8$ & 200 \\
\hline $80-5,86$ & $27.1 ?$ & 4.2 E-9 & 250 \\
\hline $80-5,132$ & 31.4 & $1.1 \mathrm{E}-8$ & 350 \\
\hline $81-1,89$ & $49.6 ?$ & 7.7 E-9 & 250 \\
\hline $81-2,128$ & $43.7 ?$ & 6.4 E-9 & 175 \\
\hline $81-3,124$ & 44.7 & $1.3 \mathrm{E}-8$ & 250 \\
\hline $81-4,55$ & $75.1 ?$ & $3.6 \mathrm{E}-9$ & 250 \\
\hline $81-4,147$ & $-37.4 ?$ & 2.3 E-9 & 250 \\
\hline $82-1,142$ & $24.5 ?$ & 5.2 E-9 & 250 \\
\hline $82-2,20$ & 35.1 & 9.8 E-9 & 250 \\
\hline
\end{tabular}

Appendix. (Continued).

\begin{tabular}{|c|c|c|c|}
\hline $\begin{array}{c}\text { Sample } \\
\text { (core-section, cm.) }\end{array}$ & $\begin{array}{c}\text { Inclination } \\
\left({ }^{\circ}\right)\end{array}$ & $\begin{array}{l}\text { Intensity } \\
\left(\mathrm{emu} / \mathrm{cm}^{3}\right)^{\mathrm{a}}\end{array}$ & $\begin{array}{l}\text { Demag step } \\
\left({ }^{\circ} \mathrm{C}\right)^{\mathrm{b}}\end{array}$ \\
\hline $82-2,66$ & $23.2 ?$ & $4.3 \mathrm{E}-9$ & 175 \\
\hline $83-1,4$ & 22.2 & $1.8 \mathrm{E}-8$ & 250 \\
\hline $83-1,115$ & -43.9 & $1.0 \mathrm{E}-7$ & 250 \\
\hline $83-2,121$ & $-11.6 ?$ & 2.2 E-9 & 200 \\
\hline $83-3,72$ & 43.4 & $1.6 \mathrm{E}-8$ & 350 \\
\hline $83-4,15$ & 8.9 & $1.5 \mathrm{E}-8$ & 250 \\
\hline $83-4,110$ & 34.5 & $1.1 \mathrm{E}-7$ & 250 \\
\hline $83-5,98$ & 28.7 & $1.9 \mathrm{E}-6$ & 350 \\
\hline $84-1,14$ & 27.7 & $8.3 \mathrm{E}-7$ & 250 \\
\hline $84-2,34$ & -19.6 & $2.7 \mathrm{E}-8$ & 250 \\
\hline $84-3,27$ & -18.7 & $5.8 \mathrm{E}-8$ & 300 \\
\hline $84-4,30$ & -25.9 & $1.2 \mathrm{E}-7$ & 250 \\
\hline $84-5,23$ & -28.9 & $1.0 \mathrm{E}-7$ & 350 \\
\hline $84-6,32$ & -32.4 & $2.2 \mathrm{E}-7$ & 250 \\
\hline $84-7,34$ & 32.1 & $2.1 \mathrm{E}-8$ & 250 \\
\hline $85-1,13$ & 35.9 & $3.0 \mathrm{E}-8$ & 250 \\
\hline $85-2,30$ & 30.7 & $4.5 \mathrm{E}-8$ & 250 \\
\hline $85-3,21$ & $61.9 ?$ & 4.4 E-9 & 250 \\
\hline $85-3,106$ & 29.9 & $6.2 \mathrm{E}-8$ & 350 \\
\hline $85-4,115$ & 37.1 & $1.1 \mathrm{E}-7$ & 250 \\
\hline $85-5,91$ & -30.8 & $2.3 \mathrm{E}-8$ & 250 \\
\hline $86-1,14$ & -37.6 & 8.2 E- 8 & 250 \\
\hline $86-2,38$ & -36.8 & $1.2 \mathrm{E}-7$ & 250 \\
\hline $86-3,28$ & -42.9 & 7.5 E-8 & 300 \\
\hline $86-4,39$ & -31.5 & $4.8 \mathrm{E}-8$ & 350 \\
\hline $86-5,6$ & -40.4 & 5.9 E-8 & 250 \\
\hline $87-1,17$ & -41.2 & $1.1 \mathrm{E}-7$ & 350 \\
\hline $87-1,138$ & -37.6 & $2.0 \mathrm{E}-7$ & 350 \\
\hline $87-2,52$ & -37.8 & $1.2 \mathrm{E}-7$ & 350 \\
\hline $87-2,137$ & -38.3 & $1.0 \mathrm{E}-7$ & 350 \\
\hline $87-3,34$ & -34.4 & $1.3 \mathrm{E}-7$ & 350 \\
\hline $87-3,130$ & -36.8 & $1.1 \mathrm{E}-7$ & 400 \\
\hline $87-4,23$ & -35.0 & $6.5 \mathrm{E}-8$ & 350 \\
\hline $87-4,122$ & -44.5 & $1.1 \mathrm{E}-7$ & 350 \\
\hline $87-5,18$ & -40.1 & $1.2 \mathrm{E}-7$ & 400 \\
\hline $87-5,136$ & 26.5 & 7.7 E-8 & 400 \\
\hline $87-6,3$ & -37.5 & $1.0 \mathrm{E}-7$ & 350 \\
\hline $88-1,11$ & -25.4 & 3.9 E-8 & 350 \\
\hline $88-1,107$ & -35.1 & $2.3 \mathrm{E}-7$ & 350 \\
\hline $88-2,16$ & -43.0 & 8.8 E- 8 & 350 \\
\hline $88-2,131$ & -43.3 & $6.8 \mathrm{E}-8$ & 350 \\
\hline $88-3,27$ & -46.2 & 8.8 E-8 & 350 \\
\hline $88-3,133$ & -42.3 & $7.3 \mathrm{E}-8$ & 350 \\
\hline $88-4,54$ & -44.7 & $1.7 \mathrm{E}-7$ & 350 \\
\hline $88-4,130$ & -31.5 & $7.0 \mathrm{E}-8$ & 350 \\
\hline $88-5,46$ & -41.3 & $5.5 \mathrm{E}-8$ & 350 \\
\hline $88-5,142$ & -43.7 & $1.1 \mathrm{E}-7$ & 350 \\
\hline $88-6,24$ & -38.8 & $1.5 \mathrm{E}-7$ & 400 \\
\hline $89-1,24$ & -26.3 & $4.8 \mathrm{E}-8$ & 400 \\
\hline $89-1,133$ & 41.6 & $4.6 \mathrm{E}-8$ & 400 \\
\hline $89-2,14$ & 47.1 & 5.0 E-8 & 350 \\
\hline $89-2,140$ & 35.9 & $9.1 \mathrm{E}-8$ & 350 \\
\hline $89-3,43$ & 34.6 & $1.5 \mathrm{E}-7$ & 350 \\
\hline $89-3,128$ & 51.5 & 8.9 E-8 & 350 \\
\hline $89-4,40$ & 35.7 & 3.6 E-7 & 350 \\
\hline $89-4,109$ & 30.8 & $5.3 \mathrm{E}-7$ & 400 \\
\hline $89-5,15$ & 31.2 & $2.2 \mathrm{E}-7$ & 400 \\
\hline $89-5,104$ & 37.6 & $1.4 \mathrm{E}-7$ & 400 \\
\hline $89-6,4$ & 35.0 & $1.1 \mathrm{E}-7$ & 400 \\
\hline $90-1,37$ & 38.4 & 8.1 E-8 & 400 \\
\hline $90-1,102$ & 39.7 & $1.1 \mathrm{E}-7$ & 400 \\
\hline $90-2,37$ & -48.3 & $5.3 \mathrm{E}-8$ & 400 \\
\hline $90-2,108$ & -35.2 & $9.2 \mathrm{E}-8$ & 400 \\
\hline $90-3,41$ & -45.6 & $5.5 \mathrm{E}-8$ & 400 \\
\hline $90-3,97$ & -34.8 & $7.7 \mathrm{E}-8$ & 400 \\
\hline $90-4,15$ & -34.6 & $6.2 \mathrm{E}-8$ & 400 \\
\hline $90-4,118$ & -46.4 & $1.3 \mathrm{E}-7$ & 400 \\
\hline
\end{tabular}


Appendix. (Continued).

\begin{tabular}{|c|c|c|c|}
\hline $\begin{array}{c}\text { Sample } \\
\text { (core-section, cm.) }\end{array}$ & $\begin{array}{l}\text { Inclination } \\
\left(\left(^{\circ}\right)\right.\end{array}$ & $\begin{array}{l}\text { Intensity } \\
\left(\mathrm{emu} / \mathrm{cm}^{3}\right)^{\mathrm{a}}\end{array}$ & $\begin{array}{l}\text { Demag step } \\
\left({ }^{\circ} \mathrm{C}\right)^{\mathrm{b}}\end{array}$ \\
\hline $90-5,38$ & -46.1 & $7.9 \mathrm{E}-8$ & 400 \\
\hline $90-5,117$ & 25.4 & $3.0 \mathrm{E}-8$ & 400 \\
\hline $91-1,26$ & 42.2 & 9.1 E-8 & 400 \\
\hline $91-1,96$ & 37.0 & 2.1 E-7 & 400 \\
\hline $91-2,22$ & 32.1 & 5.9 E-7 & 400 \\
\hline $91-2,97$ & -31.6 & 7.1 E-7 & 400 \\
\hline $91-3,8$ & 45.6 & 8.4 E-8 & 400 \\
\hline $91-3,109$ & 41.4 & 8.9 E-8 & 450 \\
\hline $91-4,21$ & 39.3 & $1.2 \mathrm{E}-7$ & 400 \\
\hline $91-4,118$ & 43.8 & $8.5 \mathrm{E}-8$ & 400 \\
\hline $91-5,35$ & 38.9 & $6.7 \mathrm{E}-8$ & 400 \\
\hline $91-5,108$ & 35.9 & $7.3 \mathrm{E}-8$ & 350 \\
\hline $91-6,31$ & 40.7 & $8.2 \mathrm{E}-8$ & 400 \\
\hline $92-1,19$ & 31.0 & $3.0 \mathrm{E}-7$ & 400 \\
\hline $92-1,119$ & 28.2 & 6.8 E-7 & 400 \\
\hline $92-2,16$ & 30.4 & $7.1 \mathrm{E}-7$ & 400 \\
\hline $92-2,79$ & 45.4 & $1.4 \mathrm{E}-7$ & 400 \\
\hline $92-2,143$ & 33.8 & $3.5 \mathrm{E}-7$ & 400 \\
\hline $92-3,40$ & 35.4 & 8.9 E-7 & 400 \\
\hline $92-3,115$ & 31.2 & $4.3 \mathrm{E}-7$ & 400 \\
\hline $92-4,6$ & 27.1 & $7.9 \mathrm{E}-7$ & 400 \\
\hline $92-4,56$ & 26.8 & $1.3 \mathrm{E}-6$ & 400 \\
\hline $92-4,140$ & 26.3 & $5.7 \mathrm{E}-7$ & 400 \\
\hline $92-5,34$ & 26.9 & $6.9 \mathrm{E}-7$ & 400 \\
\hline $92-5,89$ & 39.4 & $1.6 \mathrm{E}-7$ & 400 \\
\hline $92-5,132$ & 39.5 & 4.6 E-7 & $300+400 \mathrm{Oe}$ \\
\hline $92-6,8$ & 36.0 & $2.0 \mathrm{E}-7$ & 400 \\
\hline $92-6,56$ & $18.9 ?$ & $4.6 \mathrm{E}-8$ & 400 \\
\hline $93-1,131$ & 38.1 & $7.2 \mathrm{E}-8$ & $300+400 \mathrm{Oe}$ \\
\hline $93-2,16$ & 37.6 & $4.8 \mathrm{E}-7$ & 400 \\
\hline $93-2,66$ & 44.0 & $1.9 \mathrm{E}-8$ & 400 \\
\hline $93-2,131$ & 31.9 & $4.5 \mathrm{E}-7$ & 400 \\
\hline $93-3,29$ & 40.0 & $3.2 \mathrm{E}-7$ & 400 \\
\hline $93-3,127$ & 33.2 & $4.3 \mathrm{E}-8$ & 400 \\
\hline $93-4,14$ & 31.1 & $1.2 \mathrm{E}-6$ & 400 \\
\hline $93-4,47$ & 27.1 & $7.7 \mathrm{E}-7$ & 400 \\
\hline $94-1,17$ & 35.8 & $5.3 \mathrm{E}-7$ & 400 \\
\hline $94-1,93$ & 28.9 & $2.3 \mathrm{E}-7$ & 400 \\
\hline $94-2,9$ & 22.7 & $4.9 \mathrm{E}-6$ & 400 \\
\hline $94-2,77$ & 29.5 & 2.5 E-6 & 400 \\
\hline $94-2,135$ & 39.9 & 8.7 E-5 & 400 \\
\hline $94-3,46$ & -29.5 & 2.3 E-7 & 400 \\
\hline $94-3,124$ & 20.6 & $8.2 \mathrm{E}-7$ & $300+400 \mathrm{Oe}$ \\
\hline $94-4,7$ & -31.9 & $5.2 \mathrm{E}-7$ & 400 \\
\hline $94-4,77$ & -37.4 & $3.0 \mathrm{E}-7$ & 400 \\
\hline $95-1,15$ & -43.4 & $6.0 \mathrm{E}-7$ & 400 \\
\hline $95-1,71$ & -17.5 & $1.3 \mathrm{E}-6$ & 400 \\
\hline $95-2,65$ & 22.7 & 7.4 E-7 & $300+400 \mathrm{Oe}$ \\
\hline $95-2,120$ & -38.7 & $1.2 \mathrm{E}-6$ & 400 \\
\hline $95-3,6$ & 31.7 & $1.4 \mathrm{E}-6$ & 400 \\
\hline $95-3,73$ & 44.4 & $4.8 \mathrm{E}-8$ & 400 \\
\hline $95-3,133$ & 24.5 & $1.4 \mathrm{E}-7$ & 400 \\
\hline $95-4,26$ & 22.3 & $6.9 \mathrm{E}-7$ & 400 \\
\hline $95-4,116$ & 23.5 & $1.1 \mathrm{E}-6$ & 400 \\
\hline $95-5,38$ & 24.1 & $3.9 \mathrm{E}-6$ & 400 \\
\hline $96-1,9$ & 23.1 & $3.1 \mathrm{E}-6$ & 400 \\
\hline $96-1,106$ & 24.5 & 3.4 E-6 & 400 \\
\hline $96-2,7$ & 24.8 & $1.1 \mathrm{E}-6$ & 400 \\
\hline $96-2,101$ & -19.1 & 1.3 E-6 & 400 \\
\hline $96-3,40$ & -23.7 & $1.8 \mathrm{E}-7$ & 400 \\
\hline $96-3,103$ & -23.7 & $3.5 \mathrm{E}-7$ & 400 \\
\hline $96-4,14$ & -21.0 & $2.1 \mathrm{E}-6$ & 400 \\
\hline $96-4,80$ & -17.7 & 3.7 E-6 & 400 \\
\hline $96-5,39$ & -30.6 & $6.7 \mathrm{E}-7$ & $300+400 \mathrm{Oe}$ \\
\hline $97-1,20$ & 11.1 & 7.3 E-7 & 400 \\
\hline $97-1,34$ & 17.7 & $1.6 \mathrm{E}-6$ & 400 \\
\hline $98-0,2$ & 30.9 & $3.0 \mathrm{E}-6$ & 400 \\
\hline $99-1,21$ & 22.0 & 3.7 E-6 & 400 \\
\hline $99-1,91$ & 36.1 & 4.1 E-7 & 450 \\
\hline
\end{tabular}

Appendix. (Continued).

\begin{tabular}{|c|c|c|c|}
\hline $\begin{array}{c}\text { Sample } \\
\text { (core-section, cm.) }\end{array}$ & $\begin{array}{l}\text { Inclination } \\
\left({ }^{\circ}\right)\end{array}$ & $\begin{array}{c}\text { Intensity } \\
\left(\mathrm{emu} / \mathrm{cm}^{3}\right)^{\mathrm{a}}\end{array}$ & $\begin{array}{l}\text { Demag step } \\
\left({ }^{\circ} \mathrm{C}\right)^{b}\end{array}$ \\
\hline $99-2,41$ & 28.9 & $2.7 \mathrm{E}-6$ & 400 \\
\hline $99-2,119$ & 18.3 & 4.2 E-6 & 450 \\
\hline $99-3,67$ & 27.8 & 4.6 E-6 & 450 \\
\hline $99-4,29$ & 22.5 & $1.9 \mathrm{E}-6$ & 400 \\
\hline $100-1,106$ & 20.9 & $3.0 \mathrm{E}-6$ & 400 \\
\hline $100-2,38$ & 33.3 & $1.6 \mathrm{E}-6$ & 450 \\
\hline $100-3,36$ & 22.0 & $2.9 \mathrm{E}-6$ & 400 \\
\hline $100-3,133$ & 27.4 & 2.4 E-6 & 450 \\
\hline $100-4,13$ & 24.7 & $4.2 \mathrm{E}-6$ & 400 \\
\hline $100-4,102$ & $-8.0 ?$ & $4.5 \mathrm{E}-7$ & 550 \\
\hline $101-1,30$ & 28.4 & $3.3 \mathrm{E}-6$ & 400 \\
\hline $101-2,28$ & $-15.5 ?$ & $5.5 \mathrm{E}-6$ & 550 \\
\hline $101-3,42$ & $4.3 ?$ & $1.2 \mathrm{E}-6$ & 500 \\
\hline $101-3,110$ & $-1.7 ?$ & $1.8 \mathrm{E}-6$ & 580 \\
\hline $101-4,139$ & -14.2 & $2.6 \mathrm{E}-6$ & 550 \\
\hline $101-5,50$ & $-0.1 ?$ & 7.2 E-6 & 550 \\
\hline $101-5,133$ & $25.3 ?$ & $3.8 \mathrm{E}-7$ & 500 \\
\hline $102-1,39$ & -10.4 & 2.2 E-6 & 500 \\
\hline $102-1,139$ & $-1.9 ?$ & $1.9 \mathrm{E}-6$ & 550 \\
\hline $102-2,17$ & 15.0 & $8.3 \mathrm{E}-6$ & 500 \\
\hline $102-2,105$ & 21.4 & $1.5 \mathrm{E}-5$ & 450 \\
\hline $102-3,19$ & $0.9 ?$ & $1.3 \mathrm{E}-6$ & 500 \\
\hline $102-4,21$ & 11.3 & 5.3 E-6 & 500 \\
\hline $102-4,98$ & $-4.7 ?$ & $1.3 \mathrm{E}-6$ & 550 \\
\hline $102-5,32$ & 16.6 & 1.7 E-6 & 550 \\
\hline $102-5,123$ & $7.4 ?$ & $1.2 \mathrm{E}-6$ & 500 \\
\hline $103-1,16$ & 23.0 & $4.7 \mathrm{E}-6$ & 500 \\
\hline $103-1,71$ & $-5.8 ?$ & $1.6 \mathrm{E}-5$ & 550 \\
\hline $103-1,129$ & -29.5 & $1.0 \mathrm{E}-7$ & 400 \\
\hline $104-1,5$ & -29.8 & $1.7 \mathrm{E}-7$ & 400 \\
\hline 104,1137 & -23.0 & $2.3 \mathrm{E}-7$ & 350 \\
\hline $104-2,10$ & -26.5 & 7.4 E-8 & 400 \\
\hline $104-2,82$ & -28.9 & 9.4 E-7 & 350 \\
\hline $104-3,5$ & -29.2 & $7.5 \mathrm{E}-8$ & 350 \\
\hline $104-3,111$ & -35.9 & $3.0 \mathrm{E}-7$ & 350 \\
\hline $104-4,7$ & -11.8 & 1.5 E-5 & 460 \\
\hline $104-4,80$ & -24.8 & $6.1 \mathrm{E}-7$ & 400 \\
\hline $104-5,6$ & 21.3 & 5.2 E-6 & 400 \\
\hline $105-1,6$ & 43.6 & $7.3 \mathrm{E}-7$ & 350 \\
\hline $105-1,60$ & -31.2 & 9.3 E-7 & 350 \\
\hline $105-1,142$ & -22.4 & $2.1 \mathrm{E}-8$ & 350 \\
\hline $105-2,39$ & $-2.7 ?$ & 9.2 E-9 & 350 \\
\hline $105-2,132$ & -41.4 & $1.4 \mathrm{E}-8$ & 350 \\
\hline $105-1,14$ & -41.1 & $3.2 \mathrm{E}-8$ & 350 \\
\hline $106-1,72$ & -32.6 & $2.6 \mathrm{E}-8$ & 350 \\
\hline $106-1,127$ & -22.4 & $1.7 \mathrm{E}-7$ & 350 \\
\hline $106-2,29$ & -40.8 & 8.9 E-8 & 350 \\
\hline $106-2,79$ & -33.5 & $1.8 \mathrm{E}-8$ & 350 \\
\hline $107-1,12$ & -22.8 & $1.2 \mathrm{E}-8$ & 500 \\
\hline $107-1,96$ & -42.3 & $5.5 \mathrm{E}-8$ & 350 \\
\hline $107-2,19$ & -18.5 & $2.7 \mathrm{E}-8$ & 500 \\
\hline $108-1,12$ & -10.0 & $1.8 \mathrm{E}-7$ & 400 \\
\hline $108-1,70$ & $-3.9 ?$ & $1.0 \mathrm{E}-6$ & 520 \\
\hline $108-1,108$ & 20.7 & 2.6 E-6 & 500 \\
\hline $109-1,10$ & 25.0 & $3.6 \mathrm{E}-8$ & 400 \\
\hline $110-1,8$ & 16.1 & 8.2 E-7 & 400 \\
\hline $111-1,2$ & $-1.8 ?$ & $6.6 \mathrm{E}-8$ & 500 \\
\hline $111-1,19$ & -26.8 & 8.7 E-7 & 500 \\
\hline $112-1,13$ & -24.3 & $1.1 \mathrm{E}-6$ & 490 \\
\hline $112-1,79$ & -14.9 & $1.6 \mathrm{E}-8$ & 500 \\
\hline $113-1,10$ & 12.1 & $5.6 \mathrm{E}-8$ & 500 \\
\hline $113-1,68$ & $56.7 ?$ & $3.8 \mathrm{E}-7$ & 500 \\
\hline $114-1,70$ & 26.9 & $2.8 \mathrm{E}-7$ & 500 \\
\hline $114-2,22$ & $-6.8 ?$ & $3.3 \mathrm{E}-7$ & 500 \\
\hline $115-1,26$ & 29.8 & $1.4 \mathrm{E}-7$ & 500 \\
\hline $115-1,90$ & $51.6 ?$ & $1.1 \mathrm{E}-6$ & 500 \\
\hline $116-1,71$ & -34.6 & $6.5 \mathrm{E}-7$ & 400 \\
\hline $117-1,18$ & 21.6 & $2.5 \mathrm{E}-6$ & 400 \\
\hline $117-1,38$ & $-35.5 ?$ & $4.9 \mathrm{E}-9$ & 350 \\
\hline
\end{tabular}


Appendix. (Continued).

\begin{tabular}{cccl}
\hline $\begin{array}{c}\text { Sample } \\
\text { (core-section, cm.) }\end{array}$ & $\begin{array}{c}\text { Inclination } \\
\left({ }^{\circ}\right)\end{array}$ & $\begin{array}{c}\text { Intensity } \\
\left(\mathrm{emu} / \mathrm{cm}^{3}\right)^{\mathrm{a}}\end{array}$ & $\begin{array}{c}\text { Demag step } \\
\left({ }^{\circ} \mathrm{C}\right)\end{array}$ \\
\hline $118-1,70$ & $28.6 ?$ & $4.4 \mathrm{E}-8$ & 400 \\
$118-1,95$ & 27.7 & $8.8 \mathrm{E}-9$ & 400 \\
$119-1,108$ & 11.3 & $8.1 \mathrm{E}-7$ & 400 \\
$120-1,56$ & $45.4 ?$ & $2.3 \mathrm{E}-6$ & 500 \\
$121-1,22$ & $12.3 ?$ & $9.4 \mathrm{E}-9$ & 400 \\
$122-1,13$ & $-18.4 ?$ & $2.1 \mathrm{E}-7$ & 400 \\
$122-1,126$ & 28.9 & $1.0 \mathrm{E}-7$ & 450 \\
$122-2,29$ & $51.2 ?$ & $1.7 \mathrm{E}-7$ & 450 \\
$122-2,102$ & -21.5 & $2.9 \mathrm{E}-8$ & 430 \\
$123-1,126$ & $-21.6 ?$ & $1.1 \mathrm{E}-7$ & 450 \\
$123-2,68$ & $44.2 ?$ & $2.8 \mathrm{E}-7$ & 450 \\
$123-3,129$ & $41.0 ?$ & $1.0 \mathrm{E}-7$ & 450 \\
$123-3,130$ & $51.8 ?$ & $9.7 \mathrm{E}-8$ & 450 \\
$123-4,64$ & 35.3 & $3.3 \mathrm{E}-7$ & 350 \\
$123-4,113$ & $65.5 ?$ & $2.1 \mathrm{E}-7$ & 350 \\
$124-1,12$ & $70.7 ?$ & $4.2 \mathrm{E}-7$ & 450 \\
$124-1,49$ & $-1.5 ?$ & $1.1 \mathrm{E}-7$ & 450 \\
$124-1,82$ & $65.5 ?$ & $2.1 \mathrm{E}-7$ & 350 \\
$124-2,16$ & $7.6 ?$ & $2.3 \mathrm{E}-7$ & 450 \\
$124-2,30$ & 29.3 & $9.8 \mathrm{E}-8$ & 350 \\
$125-1,45$ & $66.4 ?$ & $1.1 \mathrm{E}-6$ & 350 \\
$125-1,124$ & 37.7 & $1.4 \mathrm{E}-6$ & 450 \\
$125-2,36$ & 31.3 & $2.8 \mathrm{E}-7$ & 430 \\
$125-2,124$ & 22.6 & $4.9 \mathrm{E}-7$ & $400+500 \mathrm{Oe}$ \\
$125-3,29$ & $-59.4 ?$ & $1.4 \mathrm{E}-6$ & 350 \\
$125-3,110$ & $-51.1 ?$ & $1.8 \mathrm{E}-7$ & 450 \\
$125-4,12$ & $67.6 ?$ & $1.4 \mathrm{E}-7$ & 350 \\
\hline & & &
\end{tabular}

Appendix. (Continued).

\begin{tabular}{lccl}
\hline $\begin{array}{c}\text { Sample } \\
\text { (core-section, cm.) }\end{array}$ & $\begin{array}{c}\text { Inclination } \\
\left({ }^{\circ}\right)\end{array}$ & $\begin{array}{c}\text { Intensity } \\
\left(\mathrm{emu} / \mathrm{cm}^{3}\right)^{\mathrm{a}}\end{array}$ & $\begin{array}{c}\text { Demag step } \\
\left({ }^{\circ} \mathrm{C}\right)^{\mathrm{b}}\end{array}$ \\
\hline $125-4,136$ & $54.9 ?$ & $7.8 \mathrm{E}-7$ & 350 \\
$125-5,20$ & $55.6 ?$ & $8.1 \mathrm{E}-7$ & 350 \\
$125-6,6$ & $45.1 ?$ & $5.6 \mathrm{E}-7$ & 350 \\
$125-6,89$ & $47.2 ?$ & $1.7 \mathrm{E}-7$ & 300 \\
$126-1,9$ & -22.9 & $8.4 \mathrm{E}-8$ & 400 \\
$126-1,97$ & $58.5 ?$ & $1.5 \mathrm{E}-6$ & 300 \\
$126-1,132$ & $50.8 ?$ & $7.4 \mathrm{E}-7$ & 300 \\
$126-2,35$ & $53.4 ?$ & $6.3 \mathrm{E}-8$ & 300 \\
$126-2,60$ & $60.9 ?$ & $3.1 \mathrm{E}-7$ & 300 \\
$126-2,122$ & -17.3 & $8.2 \mathrm{E}-8$ & 450 \\
$126-3,77$ & $50.4 ?$ & $1.0 \mathrm{E}-5$ & 300 \\
$126-3,108$ & 14.8 & $1.8 \mathrm{E}-5$ & 450 \\
$126-4,6$ & $41.8 ?$ & $3.3 \mathrm{E}-5$ & 300 \\
$127-1,24$ & $1.2 ?$ & $3.4 \mathrm{E}-6$ & 570 \\
$127-1,92$ & $85.9 ?$ & $4.6 \mathrm{E}-6$ & 430 \\
$127-2,11$ & $27.1 ?$ & $4.4 \mathrm{E}-7$ & 300 \\
$127-2,74$ & $25.0 ?$ & $2.4 \mathrm{E}-5$ & 300 \\
$127-3,16$ & $63.2 ?$ & $2.4 \mathrm{E}-5$ & 300 \\
$127-3,58$ & $4.5 ?$ & $4.7 \mathrm{E}-6$ & 450 \\
$127-3,115$ & $69.9 ?$ & $8.1 \mathrm{E}-5$ & 300 \\
$127-4,10$ & $21.8 ?$ & $2.5 \mathrm{E}-5$ & 300
\end{tabular}

$\mathrm{a}_{\mathrm{E}-9}=10^{-9}$

b Alternating field demagnetization is noted as oersteds. If the samples did not attain a reliable characteristic direction, the best demagnetization step is given and the inclination has a question mark after it. 